Review

\title{
Gastrointestinal Microbiota Dysbiosis Associated with SARS-CoV-2 Infection in Colorectal Cancer: The Implication of Probiotics
}

\author{
Frederick Odun-Ayo *(i) and Lalini Reddy *(i)
}

check for updates

Citation: Odun-Ayo, F.; Reddy, L.

Gastrointestinal Microbiota Dysbiosis Associated with SARS-CoV-2 Infection in Colorectal Cancer: The Implication of Probiotics.

Gastroenterol. Insights 2022, 13, 35-59. https://doi.org/10.3390/ gastroent13010006

Academic Editors: Tsvetelina Velikova and Radislav Nakov

Received: 15 December 2021

Accepted: 25 January 2022

Published: 7 February 2022

Publisher's Note: MDPI stays neutral with regard to jurisdictional claims in published maps and institutional affiliations.

Copyright: (c) 2022 by the authors. Licensee MDPI, Basel, Switzerland. This article is an open access article distributed under the terms and conditions of the Creative Commons Attribution (CC BY) license (https:// creativecommons.org/licenses/by/ $4.0 /)$.

\author{
Department of Biotechnology and Consumer Sciences, Faculty of Applied Sciences, District Six Campus, \\ Cape Peninsula University of Technology, Cape Town 7530, South Africa \\ * Correspondence: fredodunayo@gmail.com (F.O.-A.); reddyl@cput.ac.za (L.R.); \\ Tel.: +27-78-784-9231 (F.O.-A.); +27-83-382-9455 (L.R.)
}

\begin{abstract}
The complexity of coronavirus disease 2019 (COVID-19)'s pathophysiology is such that microbial dysbiosis in the lung and gastrointestinal (GI) microbiota may be involved in its pathogenic process. GI microbiota dysbiosis has been associated with respiratory disorders, including COVID-19, as well as sporadic colorectal cancer (CRC) through imbalanced microbiota and compromised immune response. It is pertinent to understand the possible role of probiotics in stabilizing the microbial environment and maintaining the integrity of the respiratory and GI tracts in SARS-CoV-2 induced dysbiosis and colorectal carcinogenesis. The long-term implication of SARS-CoV-2 in GI dysbiosis via microbiota-gut-lung cross-talk could increase the risk of new CRC diagnosis or worsen the condition of previously diagnosed individuals. Recent knowledge shows that the immune-modulatory response to probiotics is shifting the beneficial use of probiotics towards the treatment of various diseases. In this review, we highlight the potential impact of probiotics on SARS-CoV-2 infection associated with CRC through microbiota imbalance in COVID-19 patients.
\end{abstract}

Keywords: probiotics; gut microbiota; colorectal cancer; virus; respiratory tract infection; SARS-CoV-2; COVID-19

\section{Introduction}

The outbreak of coronavirus disease 2019 (COVID-19), which was reported from Wuhan, China in late December 2019, was caused by severe acute respiratory syndrome coronavirus-2 (SARS-CoV-2). Over 5 million deaths globally were reported as of 22 November 2021 [1]. SARS-CoV-2 belongs to the enveloped RNA viruses, the subgenus betacoronavirus of the family coronaviridae [2-4]. As the pathogenesis of COVID-19 is still unclear, recent studies have reported the possible inclusion of gastrointestinal (GI) symptoms, including diarrhea (2.0-10.1\%), nausea, and vomiting (1.0-3.6\%) in COVID-19 patients [5,6]. SARS-CoV-2 nucleic acids were found in the fecal samples and anal swabs of COVID-19 patients [7]. It was suggested that SARS-CoV-2 may enter the peripheral blood and primarily targets cells from the lung, heart, renal, and gastrointestinal tract that express angiotensin-converting enzyme-2 (ACE-2) receptor [8]. The ACE-2 receptor expressed in these target cells is recognized and bound by the SARS-CoV-2 spike glycoprotein S1 domain, which enhances the virus' attachment to the host cell $[9,10]$. Recent studies have demonstrated that TMPRSS2 [11], galectin-3 (GAL-3) [12,13], and N-acetylneuraminic acid (Neu5Ac) [14] receptors are highly expressed in the GI and lung epithelia. They are also necessary for viral cell-to-cell interaction and the subsequent entrance of SARS-CoV-2 into the host cells [15-18]. As a result, higher expression levels of ACE-2 and TMPRSS2 proteins indicate a higher risk of COVID-19 infection in colorectal cancer (CRC) patients compared to those with normal intestinal tissue [19].

The World Health Organization (WHO), through the GLOBOCAN cancer research agency, reported that 990,000 deaths were caused by CRC in 2020 [20]. Deaths attributed to 
cancer have been projected to continue rising worldwide, with an estimated 18.1 million deaths as of 2020 [20]. CRC is recognized as the second most common cancer worldwide, with high a morbidity and mortality rate [20]. CRC is a complicated association of tumor cells, non-neoplastic cells, and a huge number of microorganisms. Many alterations in the bacterial makeup of the GI microbiota have been described in CRC, implying that dysbiosis plays a crucial role in the development of CRC [21,22]. Although the microbiota's role in colorectal carcinogenesis is becoming clearer, the impact of SARS-CoV-2 on the microbial dysbiosis of the GI in CRC remains unclear.

Recent studies have demonstrated that the complexity of COVID-19's pathophysiology is such that microbial dysbiosis in the lung and GI microbiota may be involved in its pathogenic process [23-25]. GI microbiota dysbiosis has been associated with sporadic CRC $[21,26,27]$ as well as respiratory disorders, including chronic obstructive pulmonary disease [28]. The principal site for pathogen colonization is the nasopharynx, which contributes to the development of respiratory illnesses. Studies have shown that any imbalance in the mucosal nasopharyngeal microbiota may play a key role in viral respiratory infection susceptibility [29,30]. Similarly, patients with COVID-19 had a significant alteration in their GI microbiota when compared to controls [25,31]. Recent studies have linked GI microbiota dysbiosis to severe cases of SARS-CoV-2 through the imbalance of microbiota and compromised immune response [32-34]. The detection of the exact relationship between changing gut microbiota and SARS-CoV-2 infection as well as colon cancer is very complicated. Nevertheless, the role of probiotics in stabilizing the microbial environment and maintaining the integrity of the gastrointestinal tract (GIT) in SARS-CoV-2-induced dysbiosis and colorectal carcinogenesis may be worthwhile.

Probiotics are defined as "live microorganisms which when administered orally in adequate amount confer a health benefit on the host" $[35,36]$. They are described as a live microbial feed and food supplement that beneficially affects the host's intestinal tract [37]. Probiotics are non-pathogenic microbes that exert a variety of beneficial effects, such as antipathogenic effects, immunomodulatory factors, the production of key nutrients, and the development of mucosal epithelia. Products derived from bacteria or their end products cannot be considered probiotic because they are not alive when administered or during consumption [38]. One important point common to all these definitions is the ability of the probiotic to confer a beneficial effect on the health of the host. The implantation or colonization of these viable microorganisms improves the microbial balance of the intestinal tract. Viruses are the cause of nearly $90 \%$ of upper respiratory tract infections [39]. However, certain probiotic strains may prevent bacterial and viral diseases, such as gastroenteritis $[40,41]$ and respiratory tract infections (RTIs), including COVID-19 [39,42-45]. It is worth noting that not all probiotics, even those that offer GI advantages, help to reduce the risk of respiratory infection in every way. For example, Lactobacillus rhamnosus GG and Bifidobacterium animalis ssp. lactis may help the GIT, but they do not diminish the number of viruses in the nasopharynx [46]. Many in vivo and in vitro studies reveal an association between these beneficial bacteria and human immune-modulatory responses. This has led to a shift in the focus of research towards the beneficial use of probiotics in the treatment of various diseases in recent years. It is vital, therefore, to understand some of the areas regarding GIT and RTI diseases to which probiotics have been applied extensively in recent years, as well as to perform meaningful estimates for future applications, particularly in the treatment of COVID-19. Some of the more recently studied aspects of microbiota and CRC are the effects/counter effects of microbiota and probiotics on chemotherapy. In this review, we highlight the potential impact of probiotics on SARS-CoV-2 infection associated with CRC through imbalances in the microbiota.

\section{GI Microbiota and CRC}

The gut microbiota is linked to the occurrence and progression of CRC. Alterations in the immunological response, epithelial hemostasis, metabolic profile and activity, DNA damage, and abnormal cellular and molecular activities in colonocytes can all contribute to 
carcinogenesis [47-49]. The whole microbial composition of an organ or system is referred to as the human microbiome, which includes bacteria, fungi, viruses, their surrounding environmental circumstances, genomes, and host relationships [50]. The human GI microbiota consists of hundreds of types of microorganism, with an estimated value of over $10^{13}-10^{14}$ bacteria acting as a natural infection-defeating barrier. Furthermore, the microbiota plays an important role in gut homeostasis by performing a variety of defensive, structural, and metabolic functions in the intestinal epithelium, as well as the development of a healthy immune system [51]. Some of these bacteria grow and colonize the intestinal region of the host, becoming the Gl microbiota, which acts as a line of defense against pathogenic organisms. Microorganisms are spread unevenly throughout the digestive tract, including the stomach $\left(<10^{3}\right)$, duodenum $\left(<10^{3}\right)$, small intestine $\left(10^{2}-10^{3}\right)$, and large intestine $\left(10^{10}-10^{12}\right)$ [52]. The human colon consists of a complex microbial composition mostly of bacteria, which consist of more than 50 genera $[53,54]$. The bacterial composition of the colon is estimated to be as high as $10^{14}[55,56]$. The colon mostly comprises anaerobes, such as Bacteroides, Porphyromonas, Bifidobacterium, Lactobacillus, and Clostridium, which outgrow aerobes by a factor of $10^{2}-10^{3}: 1$ [57]. Some bacteria, including Bacteroides fragilis and Eubacterium rectale, inhabit discrete zones within the intestinal lumen of the human colon, while some become adherent to the mucosal surface [58]. Microorganisms may occasionally find themselves in a favorable environment for proliferation, but this is not the same habitat as their typical flora, resulting in the overgrowth and, eventually, the suppression of the normal flora [59]. The GI microbiota can exert both positive and harmful effects by modulating epithelial proliferation and differentiation, in addition to impacting host nutrition via the metabolism [60].

Several bacterial species appear to be involved in the pathogenesis of CRC $[27,61,62]$. The loss of bacterial diversity and dysbiosis are common observations in CRC. However, despite the existence of conflicting evidence, several studies have found significant changes in the mucosal and fecal microbiota of CRC patients and controls. Streptococcus gallolyticus (formerly Streptococcus bovis) is found in around 20-50\% of CRC and less than 5\% of healthy people. CRC patients were reported to have lower levels of Bifidobacterium longum, Clostridium clostridioforme, and Ruminococcus bromii than healthy people [63]. However, upon further study, Bacteroides were shown to be more prevalent in CRC tissues than in normal tissues; they were associated with an increase in IL 17 immunoreactive cells in the mucosa of CRC patients [63]. The presence of Fusobacterium nucleatum sequences was detected in CRC tumors and linked to lymph node metastasis [64]. In addition, another taxonomybased comparison study was undertaken to assess the differences between the microbiota of cancerous and neighboring non-cancerous colorectal tissues [27]. Firmicutes were the most prevalent phyla, accounting for $63.46 \%$ and $39.54 \%$ of the GI microbiota in malignant cancerous and adjacent non-cancerous tissues, respectively. This was followed by $12.77 \%$ and $19 \%$ of Bacteroidetes in the cancerous and adjacent non-cancerous colorectal tissues. This study further confirms that the genera Lactococcus, Bacteroides, Fusobacterium, Prevotella, and Streptococcus were found in greater abundance in cancerous cells than in non-cancerous cells [27]. Even though Firmicutes, Bacteroides, and lactic acid bacteria are frequently reduced, Fusobacterium and Porphyromonas are often increased [49]. It was demonstrated that the concentration of Fusobacterium within the tumor microenvironment is the most notable and consistent finding. This suggests that Fusobacterium is linked to inflammatory bowel diseases, such as ulcerative colitis and Crohn's disease, which are known to increase the risk of CRC $[27,65]$. Fusobacterium sp have virulence properties that promote their adhesion to host epithelial cells and their ability to infiltrate epithelial cells, as well as the ability to trigger host pro-inflammatory responses [61]. Fusobacterium nucleatum, a typical driving bacteria, promotes CRC carcinogenesis in $\mathrm{APC}^{\mathrm{min}}$ mice. However, the F. nucleatum cannot colonize the colon on its own. This requires the help of a few other species to form colonies, which then support the growth of Peptostreptococcus and Porphyromonas [66,67]. Lactococcus, which are commonly known to be GIT commensals with probiotic properties, were found to be over-represented in CRC patients. This implies that the microbial shifts are induced 
by the quite severe physiological and metabolic changes that occur as a result of colon carcinogenesis [68]. These species could be considered CRC bacterial passengers, according to the driver-passenger concept in CRC $[27,69]$. The "driver-passenger" paradigm proposes that a microbial leader assembles a group of disease-facilitating microorganisms to start the biological mechanisms that cause CRC. First, "driver" bacteria cause DNA damage and the malignant transformation of epithelial stem cells, resulting in a pro-oncogenic environment. After cancer begins, "passenger" bacteria that are better adapted to the tumor environment appear, such as F. nucleatum and S. gallolyticus [69,70].

In an animal study performed under germ-free conditions, it was noted that mutant mice genetically prone to CRC produce considerably fewer tumors than when they have typical microbiota [71]. Enterococcus faecalis produces extracellular genotoxins and DNAdamaging superoxide, causing the acute induction of chromosomal instability, which can contribute to the development of CRC [72]. CRC is caused by the activation of oncogenes in combination with the inactivation of tumor-suppressor genes due to mutations. In total, $85 \%$ of CRC cases involve gene mutations in APC or other tumor suppressor genes that activate the Wnt pathway, leading to chromosomal instability [73]. In the majority of CRC patients, the hyperactivation of Wnt/ $\beta$-catenin signaling is a typical characteristic. The neural cell adhesion receptor L1CAM (L1) is a target gene of $\beta$-catenin signaling activated in CRC patients' carcinoma cells, where it plays a significant role in CRC metastasis [74]. By acting as a co-transcriptional activator of Wnt target genes in the nucleus, together with the T-cell factor, $\beta$-catenin aids in the transmission of the Wnt signal to the nucleus [75]. The loss of DNA mismatch repair affects $15 \%$ of patients, resulting in a high level of microsatellite instability [76]. As demonstrated by Escherichia coli NC101, the inflammatory environment can change microbial gene functions and boost the cancer-promoting activities of specific bacterium strains [77].

\section{GI Microbiota Dysbiosis Associated with SARS-CoV-2 Infection and CRC}

The role of the digestive system and GI microbiota in SARS-CoV-2 infection evokes the idea of the gut-lung axis. This refers to the bi-directional interplay between the GI microbiota and the lungs, which can affect immune responses and influence the course of respiratory disorders [78]. Based on previous studies and findings, a unique idea of tight connections within the microbiota-gut-lung triad as related to SARS-CoV-2 infection has emerged [79]. It is believed that the interactions within this triangle could have a direct impact on the development of COVID-19, as well as its clinical symptoms and therapy, as shown in Figure 1.

One of the key aspects of the interactions within microbiota-GIT-lung cross-talk is the expression of ACE-2, which serves as an entry receptor for SARS-CoV-2 and an important regulator of inflammation that is higher in the GIT than in the lungs [25,80]. ACE-2 regulates amino acid transport in the intestinal epithelium, which has been linked to the synthesis of antimicrobial peptides affecting the makeup and function of the GI microbiota [81]. However, some gut microorganisms may influence ACE-2 expression in the opposite direction [25]. In recent studies, it has been reported that COVID-19 patients acquire dysbiotic GI microbiota $[23,31,80,82-84]$. This implies that disturbed GI microbiota may play a specific role in COVID-19's pathogenesis. It is important to note that various hypotheses were investigated to understand the association of dysbiotic GI microbiota with SARS-CoV-2 infection. Certain GI microbiota compositions have been hypothesized to be either positively or negatively linked by inflammatory cytokine levels and to be predictive of severe COVID-19, potentially through the modulation of fecal metabolites and host immunity [85]. This study further reveals that the GI microbiota may play a role in typical individuals' susceptibility to severe COVID-19 through positively associated pro-inflammatory cytokines. 


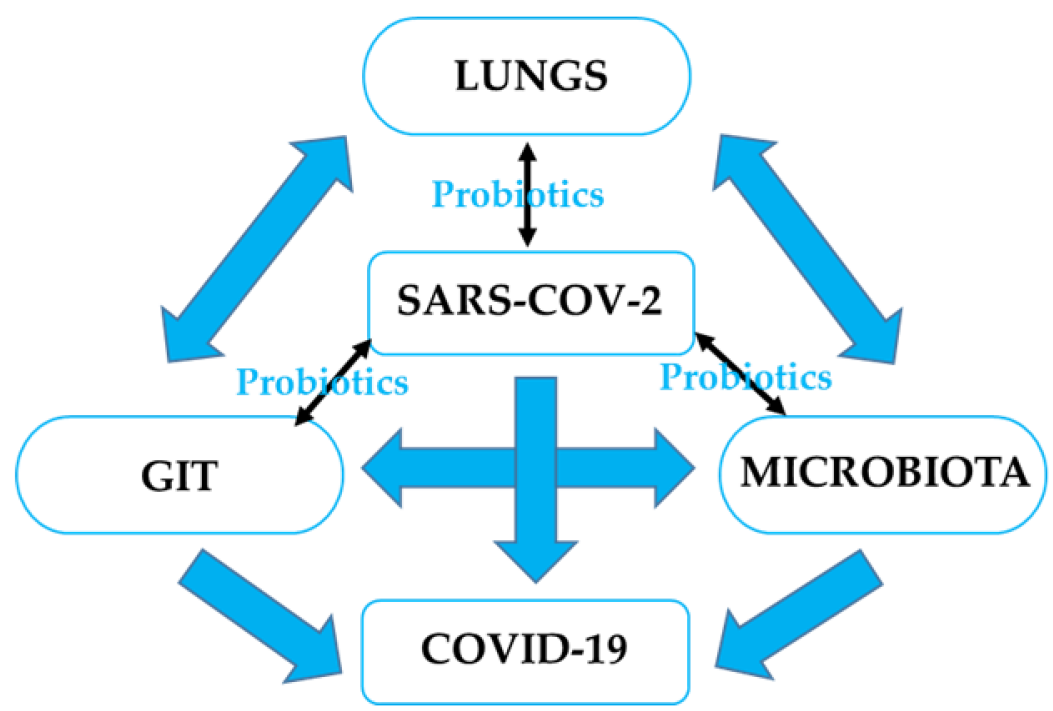

Figure 1. The interaction within the microbiota-GIT-lung could affect the development of COVID-19; hence, potential therapy through probiotic intervention could maintain microbial balance and immune modulation.

SARS-CoV-2 and COVID-19 severity were linked to alterations in the fecal microbiota. During or throughout hospitalization, patients with COVID-19 had significant abnormalities in their fecal microbiota compared to controls, characterized by the enrichment of opportunistic pathogens and the loss of beneficial commensals [25]. It was further reported that Bacteroides sp. reduce the expression of ACE-2 in the mouse gut, which is inversely related to SARS-CoV-2 burden in the patient's fecal material. Even after SARS-CoV-2 clearance (as indicated by throat swabs) and the resolution of respiratory symptoms, depleted symbionts, and gut dysbiosis persisted [25]. Bacteroides and Streptococcus genus were negatively associated with most pro-inflammatory factors. The fecal metabolomics analysis of the gut microbial from a COVID-19 patient was linked to amino acid metabolism, particularly the aminoacyl-tRNA, arginine, valine, leucine, and isoleucine biosynthesis pathways [85]. A deficiency in or insufficiency of amino acids results in the depletion of the available aminoacylated tRNA, which is essential for host immune response [86,87]; hence, the pro-inflammatory response induced by cytokines was significantly reduced [88]. As these amino acids play a key role in immunoregulation and enhancing intestinal development [89], they may invariably affect GI microbiota in COVID-19 patients and CRC.

ACE-2 and TMPRSS2 expressions have been linked to a variety of bacterial genera such as Chlamydia, which is the microbiota that has been found to be the most strongly positively correlated with ACE-2 expression in CRC patients [90]. Given that ACE-2 is highly expressed in the ileum and colon, the importance of ACE-2 is key to maintaining dietary amino acid balance and innate immunity [7]. In SARS-CoV-2 infection, the virus is attached to the host's ACE-2 receptor, with the upper airway and lungs being the predominant sites of infection. On the other hand, studies have shown that the intestinal enterocytes at the epithelial layer and the colon epithelial cells have the highest expression of ACE-2 in the human body. SARS-CoV-2 replication is aided by their support, culminating in GI barrier disruption [11,91-93], and possibly in CRC. Although the influence of the gut microbiota on COVID-19 risk in CRC patients remains poorly understood, the possible mechanisms targeting microbial dysbiosis should be further investigated [94].

During influenza infection, the inducement of interferons type I promotes the reduction of obligatory anaerobic bacteria and the enrichment of Proteobacteria in the gut, resulting in a "dysbiotic" milieu [95]. Interferons have been demonstrated to decrease antimicrobial and inflammatory responses in the GIT during Salmonella-induced colitis. This has been linked to increased Salmonella intestinal colonization and dissemination, a risk factor for CRC [96]. Salmonella can lead to protracted intestinal infection, dysbiotic gut 
microbiota, and chronic inflammation, all of which can lead to DNA damage and chromosome instability or epigenetic change. Salmonella effector proteins activate cancer-related signaling pathways. They promote the Wnt/-catenin signaling pathway during persistent infection, causing host cell change. Bacterial proteins cause leaky gut, microbiota imbalance, and inflammation, all of which contribute to the development of CRC [96]. Furthermore, in HINI influenza infection, interleukin 17A (IL-17A) signaling enhanced fast viral infiltration of the lungs by pleural cavity B-1a cells via the increase in Blimp-1 expression and NF-kB activation in B-1a cells. IL-17A deficit resulted in highly diminished B-1a-derived antibody production in the respiratory tract, leading to viral clearance deficiencies $[97,98]$. In CRC patients' tumor tissue samples, IL-17 immune cells were discovered in the majority of samples and the lamina propria of homologous normal mucosa, whereas they were rarely or not observed in normal mucosa in typical individuals. In addition, the gene amplification of Bacteroides was substantially detected at a higher level in tumor tissue compared to normal homologous tissue [63]. This implies an association between the IL-17 immune cells and Bacteroides in the mucosa cells causing dysbiosis in CRC patients. It was further reported that it was unclear why there was a link between Bacteroides density elevation and malignant CRC, as measured by qPCR [63]. It is noteworthy that the activation of proinflammatory and immunological cells in the colon mucosa is crucial in the development of cancer, as well as in the development of severe cases of COVID-19. Some GIT microbiota members may influence host mucosal regulatory T-cell responses involving Th17 cells. As a result, T-cell activation may be linked to a shift in mucosal IL-17 caused by Bacteroides, as seen in animal models $[99,100]$. These findings support the presence of a skewed immune response in CRC tissues, with IL-17 overproduction aggravating the disease, which was most likely caused by Bacteroides [101,102].

The interaction between the host immune environment and CRC or SARS-CoV-2 infection uses similar mechanisms, such as hypercoagulability, dysregulated immune response, elevated cytokine levels, altered expression of ACE-2 and TMPRSS2, and prothrombotic states. This throws the human body into disarray and may exacerbate the effects of SARS-CoV-2 in some cancer patients [103]. Numerous infiltrating plasma cells and lymphocytes with interstitial edema were detected in the lamina propria of the stomach, duodenum, and rectum [17]. Most patients infected with SARS-CoV-2 have mild GI symptoms and a good prognosis after infection, indicating that the immune function is a strong defense against this virus. Seven to fourteen days after the onset of symptoms, lymphopenia (changes in T lymphocytes) is commonly observed, with an increase in IL-6 and other inflammatory cytokines (pneumonia phase). Lymphopenia and cytokine storm syndrome lead to disease development and a poor prognosis. Lymphocytes are principally responsible for immunological responses to viral infections. However, within the first few days of infection, which is a critical stage, the rate of immune response and the level of lymphocytes produced may not be sufficient to combat or immunosuppress the rate of replication of the virus, especially in the case of SARS-CoV-2, which is new to the host body. This implies that a higher number of lymphocytes is required to compete against the virus [43], irrespective of how quickly the virus or T cell replicates. Although there are various ways for the immune defense function to eradicate infections, it is noteworthy that if the immune response is effective, viral suppression occurs. However, this may not occur if the patient has other co-morbidities, including cancer [104]. The immune dysregulation produced by SARS-CoV-2 could result in even more serious problems for an already fragile population [105].

The gut microbiota has been linked to the development of CRC. The SARS-CoV-2 infection causes changes in the gut microbiota, including the enrichment of opportunistic pathogens, the depletion of beneficial commensals, an overall drop in microbial diversity, and a loss of butyrate-producing bacteria. The increased expression of CRC carcinogenesis markers, tumor immunosuppression, and inflammation induction produced by SARS-CoV-2 infection may exacerbate CRC progression, resulting in gut barrier breakdown and the worsening of CRC advancement [105]. Regardless of the clinical stage of disease, 
patients with CRC may be at a high risk of contracting COVID-19 and are crucial protection targets in epidemic prevention. Although further validation of clinical data is needed, these findings are of practical importance. Patients with clinically mild or moderate COVID-19 with a diagnosis of CRC should be paid special attention because of a possible longer course of the disease or a higher risk of severe infection. Although further studies are required, this review lays the groundwork for the influence and impact of SARS-CoV-2 on the progression of CRC.

\section{Probiotics, GI Microbiota, CRC, and RTIs}

The term "probiotic" includes a large range of microbial organisms, main bacteria such as lactic acid bacteria (LAB), non-lactic acid bacteria, and yeasts. LAB include the genera Lactobacillus, Lactococcus, Streptococcus, Enterococcus, Leuconostoc, and Pediococcus [44,106]. Non-lactic acid bacteria include Escherichia coli Nissle and some yeasts, such as Saccharomyces cerevisiae and Saccharomyces boulardii. The most commonly used probiotic microorganisms associated with the human GIT are members of the genera Lactobacillus and Bifidobacterium. Species of the genus Lactobacillus include L. acidophilus, L. casei, L. reuteri, L. rhamnosus, L. gasseri, L. Brevis, L. amylovorous, L. crispatus, L. johnsonii, L. paracasei, and L. Plantarum, while the commonly used probiotics of the genus Bifidobacterium include B. longum, B. lactis, B. bifidum, B. infantis, and B. breve [107]. The beneficial effects of probiotics are strain-specific [108], which means the health benefits vary for different strains of probiotics. It is important to know that a considerable amount of viable probiotics should be consumed or administered by the host for effective functionality. The standard for any probiotic products must contain a minimum of $10^{6}-10^{7} \mathrm{cfu} / \mathrm{g}$ products per day $[109,110]$. The ability of probiotic bacteria to survive, multiply, and become metabolically stable in the GIT strongly determines the benefits derived by the host. The benefits associated with probiotics can be of therapeutic (protective) or nutritional significance, depending on their mode of action [38].

\subsection{The Effect of Probiotics on CRC and Other GIT Disorders}

Studies have demonstrated the beneficial effect of probiotics against CRC, as shown in Table 1. Other GIT disorders, including inflammatory bowel disease (IBD), irritable bowel syndrome (IBS), diarrhea, and obesity, are discussed [111,112].

Table 1. Various studies showing the role of probiotics on CRC.

\begin{tabular}{|c|c|c|c|c|}
\hline Disease & Model & $\begin{array}{l}\text { Dose of Probiotic } \\
\text { and Duration }\end{array}$ & Probiotic Used and Outcome & References \\
\hline \multicolumn{5}{|c|}{ In vitro } \\
\hline CRC & LS513 cell + 5-FU & $\begin{array}{l}10^{6}-10^{9} \mathrm{cfu} / \mathrm{mL} ; \\
48 \mathrm{~h}\end{array}$ & $\begin{array}{l}\text { Lactobacillus acidophilus CL1285 and Lactobacillus casei LBC80R } \\
\text { activate caspase-3 protein, downregulate p21 protein, and } \\
\text { increase the apoptosis induction capacity of 5-FU. }\end{array}$ & [113] \\
\hline CRC & $\begin{array}{l}\text { HT-29 and } \\
\text { HCT-116 cells }\end{array}$ & $\begin{array}{c}10 \mu \mathrm{g}\left(\geq 10^{7} \mathrm{cfu} / \mathrm{mL}\right) \\
72 \mathrm{~h}\end{array}$ & $\begin{array}{l}\text { Lactobacillus plantarum supernatant inhibits 5-FU-resistant } \\
\text { colorectal cancer cell lines, inhibits the expression of CD44, 133, } \\
166 \text { markers, and the ALDH1 of cancer stem cells. }\end{array}$ & [114] \\
\hline CRC & $\begin{array}{c}\text { Human } \\
\text { HCT-116 cells }\end{array}$ & $\begin{array}{l}10^{9} \mathrm{cfu} / \mathrm{mL} \\
24-72 \mathrm{~h}\end{array}$ & $\begin{array}{l}\text { L. casei ATCC } 4356 \text { and L. rhamnosus ATCC } 39,392 \text { lower MMP-9 } \\
\text { activity and increase ZO-1 protein in cultured metastatic } \\
\text { CRC cells. }\end{array}$ & [115] \\
\hline CRC & CaCo- 2 cell & $\begin{array}{l}5 \times 10^{6} \mathrm{cfu} / \mathrm{mL} ; \\
24 \mathrm{~h}\end{array}$ & $\begin{array}{l}\text { L. acidophilus and L. casei reduce cell proliferation and cell } \\
\text { migration and invasion and increase cell apoptosis. }\end{array}$ & [116] \\
\hline CRC & HT29 cell & $\begin{array}{l}0-100 \mathrm{ng} / \mathrm{mL} \\
\quad 24 \mathrm{~h}\end{array}$ & $\begin{array}{l}\text { P. freudenreichii (supernatant or metabolites) induced HT29 cell } \\
\text { apoptosis and enhanced TRAIL cytotoxic activity. }\end{array}$ & [117] \\
\hline CRC & HT29 cell & $\begin{array}{l}10^{9} \mathrm{cfu} / \mathrm{mL} \\
8 \mathrm{~h}\end{array}$ & $\begin{array}{c}\text { L. johnsonii BCRC17010 and L. reuteri BCRC14625 show an } \\
\text { increase in lactate dehydrogenase (LDH) activity inhibiting } \\
\text { HT29 cells. L. plantarum PM153 and L. johnsonii BCRC17010 } \\
\text { show good adhesion ability while the latter display potential } \\
\text { apoptotic effects. }\end{array}$ & [118] \\
\hline CRC & Caco-2 cell & $\begin{array}{l}6 \times 10^{3}-5 \times 10^{6} \text { cells; } \\
24-48 \mathrm{~h}\end{array}$ & $\begin{array}{l}\text { L. acidophilus ATCC } 314 \text { and L. fermentum } \\
\text { NCIMB } 5221 \text { reduce cell proliferation and increase apoptosis. }\end{array}$ & [119] \\
\hline
\end{tabular}


Table 1. Cont.

\begin{tabular}{|c|c|c|c|c|}
\hline Disease & Model & $\begin{array}{l}\text { Dose of Probiotic } \\
\text { and Duration }\end{array}$ & Probiotic Used and Outcome & References \\
\hline \multicolumn{5}{|c|}{ In vivo } \\
\hline $\begin{array}{l}\text { Colitis- } \\
\text { associated } \\
\text { cancer }\end{array}$ & $\begin{array}{l}6 \text { weeks old male } \\
\text { Sprague-Dawley } \\
\text { rats }\end{array}$ & $\begin{array}{l}5 \times 10^{9} \text { cfu per } 100 \mathrm{~g} \text { body } \\
\text { weight; } \\
1 \text { week }\end{array}$ & $\begin{array}{l}\text { The probiotic VSL\#3 enhances the antiangiogenic factor } \\
\text { angiostatin, VDR expression, and alkaline sphingomyelinase. }\end{array}$ & [120] \\
\hline $\begin{array}{l}\text { Acute } \\
\text { colitis }\end{array}$ & $\begin{array}{l}\text { 8-12 weeks old WT } \\
\text { C57BL/6 mice }\end{array}$ & $\begin{array}{l}10 \mu \mathrm{g} \text { in pectin/zein } \\
\text { beads/mouse/day; } \\
5 \text { days }\end{array}$ & $\begin{array}{l}\text { L. rhamnosus GG inhibits cytokine-induced apoptosis in } \\
\text { intestinal epithelial cells and the impairment of barrier function } \\
\text { in the colon epithelium, in an EGFR-dependent manner. }\end{array}$ & [121] \\
\hline CRC & $\begin{array}{l}\text { 6-8 weeks old } \\
\text { Balb/c CT26 } \\
\text { induced } \\
\text { adenocarcinoma } \\
\text { mice }\end{array}$ & $\begin{array}{l}1 \times 10^{9} \text { cfu/day; } \\
14 \text { weeks }\end{array}$ & $\begin{array}{l}\text { L. plantarum A and L. rhamnosus B up-regulates IFN and } \\
\text { promotes Th1-type CD4+ T differentiation. }\end{array}$ & [122] \\
\hline CRC & $\begin{array}{l}7 \text { weeks old male } \\
\text { AOM-induced } \\
\text { Balb/c mice }\end{array}$ & $\begin{array}{l}10 \times 10^{9} \mathrm{cfu} / \mathrm{mL} \\
\text { intragastric; } \\
\quad 4 \text { weeks }\end{array}$ & $\begin{array}{l}\text { L. acidophilus ATCC } 4356 \text { significantly increases the number of } \\
\text { fecal lactobacilli and intestinal microbiota in treated mice. }\end{array}$ & {$[123,124]$} \\
\hline CRC & $\begin{array}{l}4 \text { weeks old } \\
\text { C57BL/6J-APC } \\
\text { minin }\end{array}$ & $\begin{array}{l}0.5 \times 10^{10} \mathrm{cfu} / \text { intragastric; } \\
12 \text { weeks }\end{array}$ & $\begin{array}{c}\text { L. acidophilus ATCC } 314 \text { and L. fermentum } \\
\text { NCIMB } 5221 \text { reduces intestinal tumor multiplicity and cellular } \\
\text { marker downregulation. }\end{array}$ & [119] \\
\hline $\begin{array}{l}\text { Colitis- } \\
\text { associated } \\
\text { cancer }\end{array}$ & $\begin{array}{l}\text { AOM-induced } \\
\text { C57BL/6 mice }\end{array}$ & $\begin{array}{l}1.2 \times 10^{7} \mathrm{cfu} / \text { day; } \\
9 \text { weeks }\end{array}$ & $\begin{array}{l}\text { Probiotic Bifico reduces the abundance of Desulfovibrio, } \\
\text { Mucispirillum, Odoribacter, and Lactobacillus, which are associated } \\
\text { with the expression of CXCR2 ligand genes. }\end{array}$ & [125] \\
\hline \multirow[t]{2}{*}{ CRC } & $\begin{array}{l}\text { AOM-induced } \\
\text { Balb/c mice }\end{array}$ & $\begin{array}{l}1.5 \mathrm{~g} \text { powders of } \\
1 \times 10^{9} \mathrm{cfu} / \mathrm{g} \\
5 \text { months }\end{array}$ & $\begin{array}{l}\text { Lactobacillus acidophilus and Bifidobacterium bifidum influence the } \\
\text { expression of the tumor suppressor miRNAs and their } \\
\text { target genes. }\end{array}$ & [126] \\
\hline & \multicolumn{4}{|c|}{ Human } \\
\hline CRC & Clinical & $\begin{array}{c}10 \times 10^{9} \mathrm{cfu} / \mathrm{mL} \\
3 \text { times daily for } 12 \text { weeks }\end{array}$ & $\begin{array}{l}\text { The probiotic formula, Colon Dophilus } \\
\text { reduces the occurrence of diarrhea and enterocolitis. }\end{array}$ & [127] \\
\hline CRC & $\begin{array}{l}\text { Post-operative } \\
\text { treatment }\end{array}$ & $\begin{array}{l}0.5-1.75 \times 10^{9} \mathrm{cfu} / \text { capsule } \\
\text { twice daily; } 14 \text { days }\end{array}$ & $\begin{array}{l}\text { L. acidophilus, L. plantarum, B. lactis, and Saccharomyces boulardii } \\
\text { reduce the rate of all main complications after surgery, } \\
\text { post-operative pneumonia, and surgical site infections. }\end{array}$ & {$[128]$} \\
\hline CRC & $\begin{array}{l}\text { Post-operative } \\
\text { treatment }\end{array}$ & $\begin{array}{l}12 \mathrm{~g} \text { of sachets } / \\
10 \times 10^{11} \mathrm{cfu} \text { each } \\
\text { probiotic + prebiotics; } \\
\quad 15 \text { days }\end{array}$ & $\begin{array}{l}\text { Pediococcus pentosaceus, Leuconostoc mesenteroides, Lactobacillus } \\
\text { paracasei ssp. paracasei } 19 \text {, and Lactobacillus plantarum improve } \\
\text { postcolectomy gastrointestinal function. }\end{array}$ & [129] \\
\hline CRC & $\begin{array}{l}\text { Pre-operative } \\
\text { treatment }\end{array}$ & $\begin{array}{l}2 \text { daily tablets of } \\
1.4 \times 10^{10} \mathrm{cfu} \text { B. lactis and } \\
7 \times 10^{9} \mathrm{cfu} \text { L. acidophilus }\end{array}$ & $\begin{array}{c}\text { Reduced levels of Fusobacterium and Peptostreptococcus in fecal } \\
\text { microbiota, increased number of Faecalibacterium and } \\
\text { Clostridiales spp. in the tumor microbiota of CRC patients } \\
\text { treated with probiotics. }\end{array}$ & {$[130]$} \\
\hline
\end{tabular}

Abbreviations: 5-FU: 5-fluorouracil. ZO-1: Zona occludens-1. MMP-9: Matrix metalloproteinase-9. MCP: Modified citrus pectin. TRAIL: TNF-Related Apoptosis-Inducing Ligand. AOM: Azoxymethane. CXCR2: C-X-C motif receptor 2. LDH: Lactate dehydrogenase.

\subsubsection{CRC}

In vitro: The synergistic effect of L. acidophilus and L. casei enhanced apoptosis and reduce P21 protein when the LS513 CRC cell line was treated with the probiotics combined with 5-fluorouracil (5-FU) [113]. L. plantarum supernatant preferentially inhibits 5-FU-resistant CRC cells (HT-29 and HCT-116). The specific markers of the cancer stem cells, CD44, 133, 166, and ALDH1, were suppressed by L. plantarum. By activating caspase-3 activity, the combination therapy of L. plantarum, the supernatant, and 5-FU decreased CRC survival and led to cell death. Furthermore, this induced the inactivation of Wnt/ $\beta$ catenin signaling in chemoresistant CRC cells and lowered the formation and growth of colonospheres [114]. It was hypothesized that Propionibacterium freudenreichii and TNFrelated apoptosis-inducing ligand (TRAIL) could have a synergistic effect by acting on both extrinsic and internal death pathways, causing a pro-apoptotic response. Indeed, the whole transcriptomic analysis revealed that the supernatant or metabolites (propionate and acetate) of $P$. freudenreichii increased pro-apoptotic gene expression (TRAIL-R2/DR5) and decreased anti-apoptotic gene expression (FLIP, XIAP) in HT29 CRC cells. P. freudenreichii combined with TRAIL promoted apoptosis and increased the cytotoxic activity of TRAIL [117]. In a similar study, the combination of L. plantarum PM153 and L. johnsonii 
BCRC17010 with supernatants inhibits the proliferation of HT29 cells by inducing the secretion of nitric oxide and elevated levels of LDH [118]. The synergistic anti-cancer effect of L. acidophilus ATCC 314 and L. fermentum NCIMB 5221 significantly increases apoptosis $(p<0.001)$ as well as offering significant protection to normal colon cell growth from toxic treatment $(18.6 \pm 9.8 \%, p=0.001)$. Both the probiotic LABs influenced intestinal tumorigenesis by lowering intestinal tumor multiplicity and downregulating the expression levels of $\mathrm{Ki}-67$ and $\beta$-catenin markers [131]. HCT-116 cells were treated with cell-free supernatants from L. casei, L. rhamnosus, or Bacteroides thetaiotaomicron (a gut commensal). This altered the matrix metalloproteinase- 9 activity and levels of the tight junction protein, zona occludens-1, leading to the inhibition of colon cancer cell migration [115]. Caco-2 CRC cells treated with the probiotics, L. acidophilus ATCC 4356 and L. casei ATCC 39,392, increase cell apoptosis and reduce cell proliferation, migration, and invasion. However, no significant effect on cell necrosis was noted [132].

In vivo: Our previous study reported that the daily intake of probiotic L. acidophilus ATCC 4356 increases the total number of fecal lactobacilli by $10.2 \%\left(0.8 \pm 0.08 \log _{10} \mathrm{cfu} / \mathrm{g}\right.$; $p<0.05$ ) from the initial fecal count after 4 weeks of once-daily probiotic consumption [124]. Furthermore, the genomic sequence identification of the fecal lactobacilli showed an increase in the number of bacteria in the treated Azoxymethane (AOM)-induced colon tumor $\mathrm{Balb} / \mathrm{c}$ mouse model compared to the control. This implies that probiotics enhanced the stimulation and growth of the colonic microbiota in the CRC mouse model used in the study [123]. In a further study, the percentage of colonic pre-cancerous lesions in the probiotic-treated groups was low (20\%) compared to the untreated control group (40-50\%). In addition, there was a significant reduction in the tumors in the probiotic-treated groups compared to the control group $(p<0.05)$ [133]. It was noted that treatment with the probiotic VSL\#3 consisting of eight different strains, B breve, B. infantis, B. longum, L. acidophilus, L. bulgaricus, L. casei, L. plantarum, and S. salivarus ssp thermophiles, prevents the development of tumors and high-grade dysplasia in the proximal and mid-colon in rats. This correlates with the decreased richness and diversity of mucosally adherent microbiota in the colon. This implies that VSL\#3 can reduce a number of inflammatory-related factors, preventing the onset of dysplasia and cancer [120]. The potential effect of L. Plantarum A and $L$. rhamnosus $\mathrm{B}$ on the inducement of anti-tumor immune responses was demonstrated by pre-inoculating Balb/c mice subcutaneously with CT26 murine adenocarcinoma cells. In comparison to mice treated with L. rhamnosus, the oral administration of L. plantarum decreased CT26 cell development in the Balb/c mice and prolonged the survival time of tumor-bearing mice. The L. plantarum provided protective immunity against the challenge with CT26 cells by activating the effector functions of CD8+ and natural killer cell infiltration into cancer tissue. This up-regulated interferon (but not IL-4 or IL-17) production and promoted Th1-type CD4+ T differentiation [122]. Probiotic Bifico containing $1.0 \times 10^{7} \mathrm{cfu}$ lyophilized B. longum, L. acidophilus, and E. faecalis decreased tumor development and lowered intestinal inflammation. Furthermore, a collection of genes, including CXCL1, CXCL2, CXCL3, and CXCL5, were identified as possible Bifico therapy targets. According to $16 \mathrm{~S}$ rRNA sequencing, Bifico lowered the abundance of Desulfovibrio, Mucispirillum, Odoribacter, and Lactobacillus, which was substantially related to the expression of CXC motif receptor 2 ligand genes [125]. Another study reported that L. acidophilus and B. bifidum affected the expression of miRNAs 135b, 26b, 18a, and 155, as well as their target genes, such as APC, PTEN, KRAS, and PU.1, in an AOM-induced CRC mouse model. The expressions of the tumor suppressors miR-135b, miR-155, and KRAS all increased [126].

Human: The microbiota composition of patients with colon cancer was compared to that of non-neoplastic controls. Patients with normal mucosa and tumors were administered 2 tablets of $1.4 \times 10^{10} \mathrm{cfu}$ of B. lactis Bl-04 and $7 \times 10^{9} \mathrm{cfu}$ of L. acidophilus NCFM daily. The 16S rRNA gene amplicon sequencing of fecal and colonic samples showed increased Fusobacterium, Selenomonas, and Peptostreptococcus in the tumor microbiota compared to the control [130]. A meta-analysis was conducted to determine the effect of probiotics, including Bifidobacterium and Escherichia, on the intestinal mucosa barrier in CRC after 
surgery. It was observed that the probiotics effectively protected the intestinal mucosa's physical and biological barriers in the patients with CRC after operation [134]. The immunemodulatory effect of probiotics on the intestinal gut is a biotherapeutic/preventive strategy, as probiotics inhibit the colonization of the intestinal microbiota and the translocation of pathogens to other sites [135-138]. Most diseases that are common to the human large bowel emanate from the distal colon, most notably CRC. However, it has been noted that proximal CRC is also increasing. A gene sequencing comparison study showed that $59.6 \%$ of the bacterial genera were identified in the proximal colon and $71.6 \%$ in the distal colon of the CRC. This suggests that microbial diversity increases from the proximal colon to the distal colon in rectal malignancy. Prevotella, Pyramidobacterium, Selenomonas, and Peptostreptoccus were found in greater numbers in proximal tumors, while Fusobacterium, Escherichia-Shigella, and Leptotrichia were relatively prevalent in distal CRC [27]. Patients undergoing CRC surgery were enrolled in a randomized, double-blind, placebo-controlled study. Capsules of placebo or formulation including L. acidophilus LA-5, L. plantarum, B. lactis BB-12, and Saccharomyces boulardii were given a day before surgery and continued for another 15 days post-operatively. On day 4, the gene expression and cytokine levels in the blood were examined. The probiotics considerably reduced the rate of all the main complications after surgery, as well as reducing post-operative pneumonia and surgical site infections [128].

\subsubsection{IBD}

IBD, including Crohn's disease and ulcerative colitis, is a group of disorders characterized by chronic or recurrent inflammation of the mucosal lining marked by an autoimmune response, usually by the body's immune system. Probiotic administration regulates innate inflammatory responses in the mucosa through the modulation of the gut microbiota composition and its effect on the epithelial and T cells on the surface of the lamina propria of the gut. It was demonstrated that the colon-specific probiotic, L. rhamnosus GG, suppresses inflammation and reduces apoptosis by activating the epithelial growth factor receptor [121]. The secretion of IgA antibody is one of the basic immunological responses induced by Bifidobacterium sp.'s binding to specific receptors on the intestinal epithelial surface and subsequent release into the intestinal lumen [52]. L. salivarius Ls33 showed an anti-inflammatory effect in a colitis mouse model through the recognition of bacterial peptidoglycan and protein-derived mucopeptides [139]. Probiotics such as non-pathogenic Escherichia coli, Bifidobacterium sp., and Saccharomyces boulardii have shown efficacy in reducing the post-operative recurrence and relapse in Crohn's disease. A metaanalysis evaluation was performed to justify the effect of probiotics on Crohn's disease compared to a placebo for the prevention of post-operative recurrence, which effectively defines the preventative and therapeutic role of probiotics [140].

\subsubsection{IBS}

IBS is a functional disorder in the colon that is characterized by symptoms of abdominal discomfort, usually related to disturbed defecation (motility of the colon), which causes a drastic reduction in beneficial gut bacteria. L. rhamnosus GG was reported to have little effect on IBS, while L. plantarum $299 \mathrm{~V}$ had a significant beneficial effect [141]. Notable stability in the microbiota composition reduces abdominal pain and bowel distension when different species of probiotic supplements were administered, including L. rhamnosus Lc705, L. rhamnosus GG, B. animalis ssp. lactis $\mathrm{Bb} 12$, and P. freudenreichii ssp. Shermanii JS [142]. A clinical trial meta-analysis was conducted on the effectiveness of probiotics in the prevention of IBS and probiotic therapy. For instance, probiotic VSL\#3 reduces the clinical symptoms and abdominal pain of IBS [143]. Multispecies probiotic supplementation on IBS stimulates the microbial composition of the colon compared to single species, leading to improved bowel movement and replenishing the loss of beneficial gut bacteria. 


\subsubsection{Diarrhea}

The efficacy of probiotics in cases of infectious diarrhea has reduced the occurrence of diarrheal episodes, early symptoms, and even rotavirus infection [144-146]. The administration of L. rhamnosus GG associated with oral rehydration therapy, once or twice daily, has effectively helped in the treatment of rotavirus-associated diarrhea. It further reduces the presence of the virus in stools, thus offering an effective strategy to control the spread of nosocomial gastrointestinal infection $[147,148]$. The treatment of gastroenteritis by the probiotic, L. paracasei ST1, improved non-rotavirus diarrhea condition in children but did not affect rotavirus gastroenteritis [149]. Clostridium difficile caused about 10-20\% of antibiotic-associated diarrhea. A double-blind placebo-controlled study showed that the oral consumption of a probiotic preparation of L. bulgaricus, L. casei, and S. thermophilus invariably reduced the incidence of $C$. difficile-associated diarrhea [143]. A study was conducted to determine how efficient probiotics are at preventing irinotecan-induced diarrhea by lowering intestinal $\beta$-D-glucuronidase activity. The probiotic formula, Colon Dophilus $^{\mathrm{TM}}$, was administered orally at a dose of $10 \times 10^{9} \mathrm{cfu} / \mathrm{mL}$ of bacteria three times daily for 12 weeks to CRC patients starting a new line of irinotecan-based therapy; the results were compared with those from a placebo-treated group [127].

\subsubsection{Obesity}

Obesity is closely related in terms of risk factors for CRC. It was suggested that infants presenting with a low level of Bifidobacterium sp. and a higher number of Staphylococcus aureus in their stool are at a higher risk of obesity. A mouse model study demonstrated that the transplantation of microbial communities within the gut could manipulate the propensity for the deposition of fat. The administration of probiotics influences the intestinal microbiota, inhibiting susceptibility to obesity. This suggests a possible probiotic therapy that may prove to be a strategy for controlling childhood obesity $[137,150]$. In a randomized placebo-controlled trial, fermented milk containing L. gasseri SBT2055 was administered to healthy and obese patients. A decrease in fat, body weight, and mass index was observed compared to the control group [151]. Probiotics interact with the endogenous bacteria in the gut by modifying or regulating fat metabolic pathways. Although the energy intake was less affected, the administration of L. rhamnosus PL60 in diet-induced obese mice led to a significant loss of body weight by reducing the mass of white adipose tissue [135].

\subsubsection{Possible Mechanism of Probiotics}

Even though various studies have sought to explain the mechanism of probiotics' anticarcinogenic properties, a definite mechanism for probiotic anti-CRC activity is yet to be discovered [152-154]. Possible mechanisms may involve the cell cycle, apoptosis, reactive oxygen species (ROS), the production of specific bacterial metabolic enzymes, and effects on host metabolism. However, other mechanisms were also suggested, including the alteration of quantitative and/or qualitative intestinal microbiota involved in the production of carcinogens and promoters; the alteration of the physicochemical conditions in the colon; the production of anti-tumourigenic or anti-mutagenic compounds; the enhancement of the host immune response system; the effect on host physiology; and the binding and degradation of potential carcinogens, including mutagenic compounds [131,152-156].

The G1 phase is an important early phase in the cell cycle that is necessary for cell proliferation. L. rhamnosus GG induces an anti-proliferative effect in cancer cell lines by reducing the biosynthesis of polyamines. These may also be a result of the Lactobacilli's ability to adhere to cells, inducing apoptosis, which eventually may prevent the proliferation of colon cancer [157]. The presence of reactive oxygen species (ROS) is a prominent event in colon inflammation. The antioxidant properties of probiotic strains can inhibit/or reduce this effect and thereby increase probiotic gut colonization [158-160]. The interaction between the epithelial cells and the microbiota gut is an active process that can be induced by the presence of probiotics in the production of pro-inflammatory cytokines. Interleukin 12 (IL-12) can be induced after the activation of the innate immune system by some Lacto- 
bacilli strains stimulating dendritic cells, native $\mathrm{T}$ cells in the lamina propria of the gut, and macrophages [154,161].

The probiotic effect of the alteration of quantitative intestinal microbiota has been suggested. A daily intake of probiotic L. acidophilus ATCC 4356 with MCP altered the number of colonic microbiota in the CRC mouse model. It is plausible that the MCP modifies the functionality and physiological properties of the probiotic during gastric transit, causing adhesion/colonization within the microbiota environment $[123,124]$. Chronic inflammation, which disrupts the gut microbiota, is one of the fatal factors linked to the development of CRC [69]. The formation of immunity against invading pathogens and the maturation of the immune system requires a healthy gut microbiota. Probiotic supplementation improves the immune system by modulating the release of anti-inflammatory cytokines and their related regulatory genes $[162,163]$.

One important function of GI microbiota is the ability to catabolize complex polysaccharides into short-chain fatty acids (SCFAs), such as butyrate, lactic acids, acetic acid, and propionate, which are major energy sources for the epithelium cells of the colon [164-166]. In our previous study, using an azoxymethane-induced colon cancer mouse model, we observed that the fermentation of modified citrus pectin and starch by L. acidophilus ATCC 4356 and intestinal microbiota possibly increased the production of SFCAs, gases, and butyrate [124]. Fecal lactobacilli utilize butyrate as the preferred energy source for their growth and the proliferation of colonic epithelial cells. These SFCAs reduce the effect of bile in the intestine by initiating bile salt hydrolase, which deconjugates bile acid [22,167]. Previous studies reported that Lactobacilli in the GI lower the risk of CRC by displacing other bacteria, such as Bacteroides and Clostridium genera, that may produce fecal enzymes or toxins (carcinogen) during metabolism $[168,169]$. L. plantarum LS/07 was reported to have a protective effect on colon cancer-induced DNA damage in the colon cells of rats. The metabolic activity of the Lactobacilli lowers the level of colonic/fecal enzymes, such as $\beta$-glucosidase and $\beta$-glucuronidase, which hydrolyze many glucuronide-releasing carcinogens in the intestinal tract, causing CRC $[170,171]$. The ability of this colonic microbiota to produce SCFA and low levels of some colonic enzymes, such as $\beta$-glucoronidase, is suggested as the main process that prevents CRC [172]. The Bifidobacterium genome has been shown to contain some metabolic enzymes that the bacteria produce to alter the nutrient composition of the environment. This invariably adjusts their physiology; consequently, they adapt to new conditions. B. adolescentis SPM0212 was reported to exhibit bacterial enzyme activities and some anti-cancer properties, including: the inhibition of the proliferation of certain human cancer cell lines; the inhibition of harmful fecal enzymes, such as $\beta$-glucuronidase, $\beta$-glucosidase, tryptophanase, and urease; and the dose-dependent inhibition of the production of TNF- $\alpha$ [173].

Bacterial enzymes, such as $\beta$-glucuronidase, can hydrolyze many glucuronides, thereby releasing metabolites into the intestinal tract [174]. Based on animal and human studies, the consumption of LABs can reduce fecal enzyme levels, which may be involved in the formation of toxins. In one study, the effect of L. acidophilus NCFM and L. acidophilus $\mathrm{N}-2$ on 21 healthy people was evaluated for 10 days by checking the activity levels of $\beta$-glucuronidase, nitroreductase, and azoreductase, which resulted in a decrease in specific activities of these enzymes. The administration of L. rhamnosus LC705 and Propionibacterium freudenreichii ssp. Shermanii JS to 38 healthy men for 4 weeks decreased the activity of $\beta$-glucosidase and increased the fecal count of Lactobacilli and Propionibacteria in the subjects [175]. GIT is dominated by the Lactobacilli sp., which contributes to the metabolic activities taking place in this part of the host body. A hypothesis concerning colon carcinogenesis is that bile acids in the aqueous phase of feces exert cytotoxic effects on colonic epithelium cells, thereby causing an increase in cell proliferation in the intestine $[176,177]$. Some studies have shown significant decreases in bile acid with the intake of Lactobacilli sp. Mutagenic compounds in food diets bind to the cells of Lactobacilli strains and the intestinal wall after exposure, resulting in a reduction in the ratio of bound to free toxins within the 
intestine. The colonic mucosa can absorb mutagenic compounds and pass them into the bloodstream as either modified or unmodified metabolites from the intestinal lumen [152].

\subsection{The Potential Effect of Probiotics on RTIs, including SARS-CoV-2 Infection, and Possible Mechanisms}

Several strains of probiotic bacteria have a favorable impact on a wide range of defenserelated processes in the host. Although numerous studies have focused on the effects of probiotic microorganisms on intestinal pathogens, few have focused on their impact on infections in other organ systems, particularly the respiratory tract. Previous clinical studies have demonstrated the effects of probiotics on reducing the incidence and symptoms of RTI in the host [40,42,178-185], as shown in Table 2. In a randomized, placebo-controlled, double-blind intervention study conducted on otherwise healthy individuals, consuming particular probiotic bacteria for at least three months impacted the severity of symptoms, as well as the prevalence and duration of infections through enhanced cellular immune response [178]. Furthermore, it was noted that during the first 14 days of supplementation, the probiotic-treated group had a considerably larger increase in cytotoxic T-cells plus T suppressor cells (CD8+) than the control group. L. casei DN-114 001 was linked to a shorter duration of common infectious disease in the elderly, notably for upper respiratory tract infections (URTIs), such as rhinopharyngitis [42]. A review report by the Cochrane collaboration group showed that probiotics were found to be superior to placebo at reducing the number of participants who experienced acute URTI episodes by around $47 \%$ and the duration of the episode by about 1.89 days [186].

Table 2. The effects of probiotics on various respiratory tract infections.

\begin{tabular}{|c|c|c|c|c|c|}
\hline Disease & Study & Infection & Dose and Duration & Mode of Action and Outcome & References \\
\hline Influenza & Clinical & Viral & $\begin{array}{c}5 \times 10^{7} \mathrm{cfu} / \text { one tablet } \\
\text { per day; } \\
14 \text { days }\end{array}$ & $\begin{array}{l}\text { Lactobacillus gasseri PA 16/8, Bifidobacterium longum } \\
\text { SP } 07 / 3 \text {, and Bifidobacterium bifidum MF } \\
20 / 5 \text { significantly enhance cytotoxic plus T } \\
\text { suppressor (CD8+) and T helper (CD4+) cells, thus } \\
\text { reducing the symptoms and duration of common } \\
\text { cold episodes and fever, }\end{array}$ & {$[178]$} \\
\hline RTI & Clinical & $\begin{array}{l}\text { Viral and } \\
\text { bacterial }\end{array}$ & $\begin{array}{l}10^{10} \mathrm{cfu} / 100 \mathrm{~g} \text { of the } \\
\text { probiotic; } \\
3 \text { months }\end{array}$ & $\begin{array}{l}\text { Lactobacillus casei DN-114 } 001 \text { significantly reduces } \\
\text { RTI duration and rhinopharyngitis. }\end{array}$ & {$[42]$} \\
\hline Influenza & Clinical & Viral & $\begin{array}{l}1 \times 10^{11} \mathrm{cfu} ; \\
5 \text { weeks }\end{array}$ & $\begin{array}{l}\text { B. longum BB536 reduces the occurrence of } \\
\text { influenza and fever, most likely by enhancing } \\
\text { innate immunity. }\end{array}$ & [181] \\
\hline Influenza & Clinical & Viral & $\begin{array}{l}6 \times 10^{9} \mathrm{cfu} \\
8 \text { weeks }\end{array}$ & $\begin{array}{l}\text { Lactobacillus brevis KB290 reduces influenza } \\
\text { infection among children. }\end{array}$ & [184] \\
\hline Influenza & $\begin{array}{l}\text { In vivo } \\
(6 \text { week-old } \\
\text { female Balb/c } \\
\text { mice })\end{array}$ & Viral & $\begin{array}{l}2.0 \times 10^{9} \text { cfu per day; } \\
17 \text { days }\end{array}$ & $\begin{array}{l}\text { B. longum MM-2 decreases virus titers, cell death, } \\
\text { and pro-inflammatory cytokines such as IL- } 6 \text { and } \\
\text { TNF- } \alpha \text {. }\end{array}$ & {$[179]$} \\
\hline Influenza & Clinical & Viral & $\begin{array}{l}1 \times 10^{11} \text { cfu per day; } \\
10 \text { weeks }\end{array}$ & $\begin{array}{l}\text { Lactococcus lactis ssp. lactis JCM5805 enhances } \\
\text { activation and increases IFN- } \alpha \text { mediated response. }\end{array}$ & [187] \\
\hline RTI & Clinical & Viral & $\begin{array}{l}10^{9} \text { cfu per } \\
\text { capsule/ } 2 \text { capsules } \\
\text { per day; } 6 \text { months }\end{array}$ & $\begin{array}{l}\text { Lactobacillus rhamnosus GG significantly reduces } \\
\text { RTI duration. }\end{array}$ & [188] \\
\hline Influenza & $\begin{array}{l}\text { In vivo } \\
\text { (7 week-old } \\
\text { female Balb/c } \\
\text { mice })\end{array}$ & Viral & $\begin{array}{l}20 \mu \mathrm{L} \text { at a concentration } \\
\text { of } 10 \mathrm{mg} / \mathrm{mL}^{-1}(200 \mu \mathrm{g} \\
\text { per mouse once daily; } \\
\quad 3 \text { days }\end{array}$ & $\begin{array}{c}\text { L. rhamnosus GG improves the level of IFN- } \gamma \text {, } \\
\text { proinflammatory factors, and immunoregulatory } \\
\text { cytokines such as IL-12, which allow the clearance } \\
\text { of virus with minimal inflammatory lung } \\
\text { tissue damage. }\end{array}$ & {$[185,189]$} \\
\hline Influenza & Clinical & Viral & $\begin{array}{l}1 \times 10^{9} \mathrm{cfu} / \mathrm{mL} \\
\text { once daily; } \\
3 \text { weeks }\end{array}$ & $\begin{array}{c}\text { Lactobacillus delbrueckii ssp. bulgaricus OLL1073R-1 } \\
\text { and Streptococcus thermophilus OLS3059 activate } \\
\text { natural killer (NK) cell activity and induce IFN- } \gamma \\
\text { production. }\end{array}$ & [190] \\
\hline
\end{tabular}


Table 2. Cont.

\begin{tabular}{|c|c|c|c|c|c|}
\hline Disease & Study & Infection & Dose and Duration & Mode of Action and Outcome & References \\
\hline $\begin{array}{l}\text { LRTI and } \\
\text { rhinovirus } \\
\text { infection }\end{array}$ & Clinical & Viral & $\begin{array}{l}10^{9} \mathrm{cfu} / \text { capsule/seven } \\
\text { daily doses; } \\
60 \text { days }\end{array}$ & $\begin{array}{l}\text { L. rhamnosus GG reduces LRTI and the incidence of } \\
\text { rhinovirus-induced episodes in children. }\end{array}$ & [191] \\
\hline $\begin{array}{l}\text { rhinovirus } \\
\text { infection }\end{array}$ & Clinical & Viral & $\begin{array}{l}\geq 2 \times 10^{9} \mathrm{cfu} / \text { satchet } \\
\text { daily dose; } 28 \text { days }\end{array}$ & $\begin{array}{l}\text { B. animalis subspecies lactis } \mathrm{Bl}-04 \\
\text { reduces nasal lavage virus titer and influences the } \\
\text { innate immune response in the nasal cavity. }\end{array}$ & [183] \\
\hline URTI & Clinical & Viral & $\begin{array}{l}1 \times 10^{9} \mathrm{cfu} / \text { subjects } \\
\text { once daily; } 6 \text { weeks }\end{array}$ & $\begin{array}{c}\text { L. paracasei subsp. Paracasei and L. casei } 431 \text { reduce } \\
\text { the frequency of RTI episodes. }\end{array}$ & [192] \\
\hline Coronavirus & $\begin{array}{l}\text { In vitro } \\
\text { (IPEC-J2 cell } \\
\text { line) }\end{array}$ & Viral & $\begin{array}{l}2 \times 10^{6} \text { recombinant } \\
\text { cells; } 2 \mathrm{~h}\end{array}$ & $\begin{array}{l}\text { L. plantarum enhances the expression levels of IFN } \\
\text { stimulated genes, thus suppressing the viral } \\
\text { infection. }\end{array}$ & [180] \\
\hline COVID-19 & $\begin{array}{l}\text { In silico } \\
\text { docking }\end{array}$ & Viral & $\begin{array}{l}\text { Probiotics-derived } \\
\text { peptides were docked } \\
\text { targeting viral proteins }\end{array}$ & $\begin{array}{l}\text { Probiotics-derived polypeptides show strong } \\
\text { affinity binding to the S1-protein receptor-binding } \\
\text { domain of SARS-CoV-2 }\end{array}$ & [43] \\
\hline
\end{tabular}

Abbreviations: RTI: Respiratory tract infection. IL-6: Interleukin 6. TNF- $\alpha$ : Tumor necrosis factor $\alpha$. IL-10: Interleukin 10. IFN- $\gamma$ : Interferon $\gamma$. IPEC-J2: Intestinal porcine epithelial cell line J2. SARS-CoV-2: Severe acute respiratory syndrome coronavirus-2. COVID-19: Coronavirus disease 2019.

The relevance of probiotics in the treatment of coronaviruses remains controversial as the mechanisms may not be fully known yet and very little information is available. Based on previous studies and many pieces of clinical evidence for the positive effect of probiotics as supplements or adjuvants against primary and/or secondary (bacterial and viral) diseases, the existence of a basic mechanism of action of probiotics in the prevention or reduce SARS-CoV-2 infection and its importance to COVID-19 may not be far-fetched.

\subsubsection{Microbial Dysbiosis and GIT-Lung Stability Cross-Talk}

The intervention of probiotics in the interactions within microbiota-GIT-lung crosstalk could contribute to the enhancement of the intestinal epithelial barrier, competition with pathogens for nutrients, and adherence to the intestinal epithelium. The generation of antimicrobial compounds and the manipulation of the host immune system are all mechanisms that could explain probiotics' therapeutic success [39], as shown in Figure 2. Many microbial metabolites and endotoxins from the GIT can affect the lungs and vice versa when they cross the GIT-blood barrier. Furthermore, the microbiota can be affected by lung inflammation [78] through the production of several metabolites with antiviral properties, such as lactic acid, hydrogen peroxides to stimulate interleukins, natural killer cells, and Th1 helper immune responses [193].

Different strains of probiotic revealed a strain-specific potential for improving the intestinal epithelium's reliability and controlling immunological components. The GIT from the oral cavity to the rectum is regarded as the principal immunological barrier with the environment in controlling compound-mediated immune reactions. It has been demonstrated that probiotic microorganisms can connect to an invading virus and thereby inhibit the viral structural protein from binding to the host cell receptor, preventing viral entry into human cells $[194,195]$. Probiotic bacteria cling to the epithelial surface and use steric interference to prevent viral attachment by competing for specific carbohydrate receptors or by covering the receptor sites in a nonspecific manner [196]. Recent studies have identified GAL-3 as a binding mediator in the attachment and entrance of viruses, including influenza A H5N1 virus, into the host cell $[197,198]$. This is in addition to ACE-2, which has been identified as a therapeutic target to mitigate SARS-CoV-2 entry and replication in the host cell [199]. In our previous study, the S-glycoprotein layer of probiotic L. acidophilus ATCC 4356 comprising both the amino and carboxyl-terminal domains competed with the intestinal microbiota to bind to the GAL-3 COOH terminal carbohydrate recognition domain in a colonic cancer model. The initiation of the colonization/adhesion of the probiotic bacteria to specific receptors, such as GAL-3, on the epithelial cell surface of the colon may competitively inhibit GAL-3 extracellular matrix interactions in addition 
to probiotic-GAL-3 binding [133]. As a result, the probiotic significantly increases fecal lactobacilli and improves the integrity of the colonic intestinal microbiota [123,124,133]. Another study found that probiotic supplementation is an effective method for preventing viral RTIs in pre-term infants throughout their first year of life. The findings revealed that probiotic-induced changes in the GI microbiota result in the production of long-lasting effects that can minimize the incidence of viral RTIs [191].

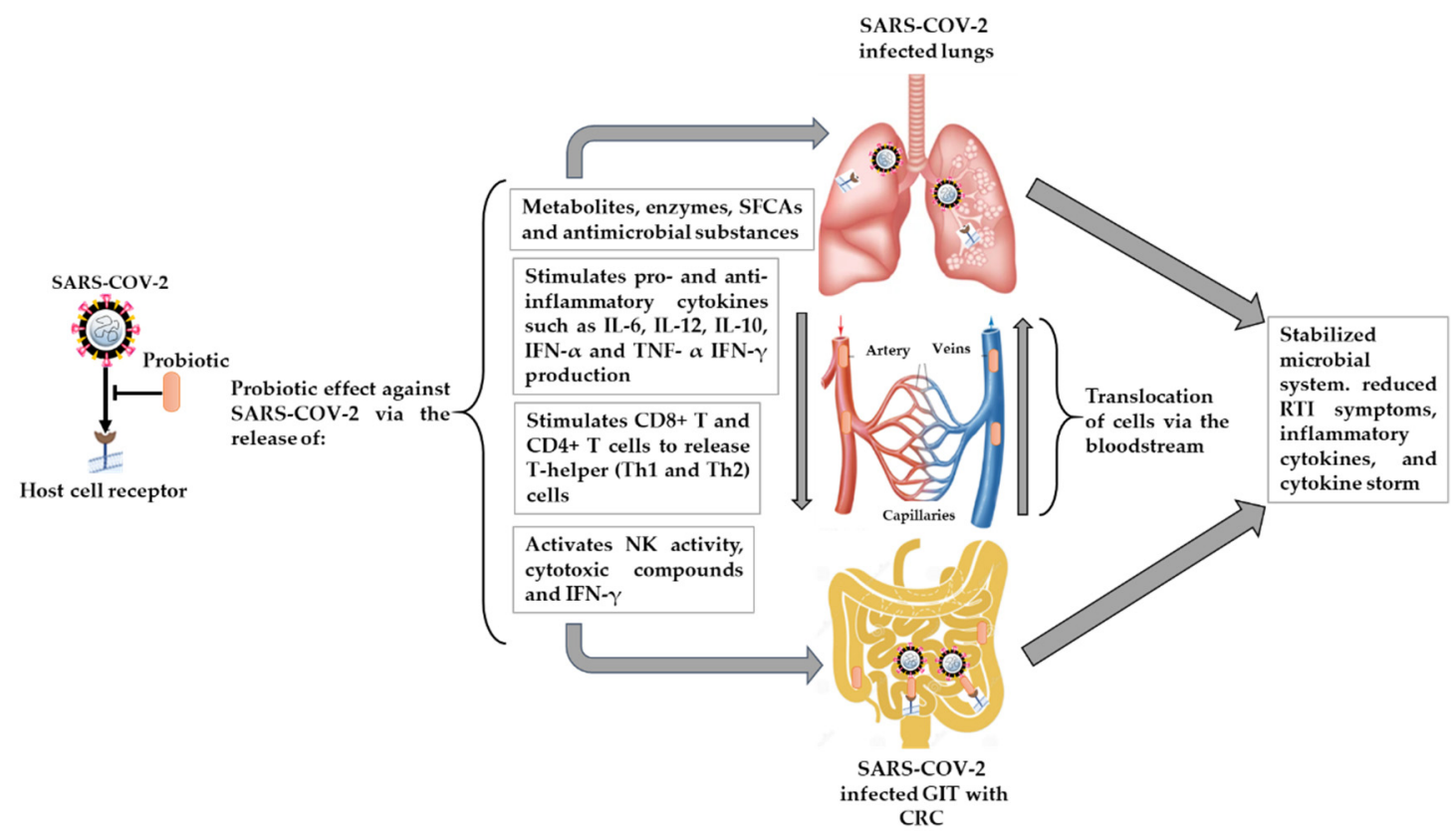

Figure 2. Immunomodulatory response and possible mechanism of probiotics effect in GI dysbiosis associated with SARS-CoV-2 infection and CRC. The potential probiotic effect against the attachment of SARS-CoV-2 to the spike protein receptor may take place through the production of certain metabolites, enzymes, SFCAs, inflammatory cytokines, T-helper cells, and cytotoxic compounds. This intervention could influence microbiota dysbiosis within the areas of infection, such as the lung and the GIT (colon), to stabilize the microbial system, reduce the symptoms or severity of RTI and proinflammatory cytokines and, consequently, reduce the cytokine storm effect in SARS-CoV-2 infection.

\subsubsection{Immunomodulatory Effects}

Some probiotic strains can help prevent bacterial and viral diseases, such as gastroenteritis, sepsis, and respiratory infections through immunomodulatory responses. By reducing pro-inflammatory signals and maintaining gut barrier integrity, probiotics can help patients maintain immunological homeostasis in the gut and avoid the overactivation of the immune response. Certain strains of Bifidobacterium and Lactobacilli were given to help eliminate the influenza virus from the respiratory system with little inflammatory damage to the lung tissue [185]. The probiotic strains impact the modulation of a systemic equilibrium between pro-inflammatory and anti-inflammatory immunoregulatory cytokines [185]. This could be important in preventing acute respiratory diseases, a significant COVID-19 consequence. A probiotic using L. plantarum DR7 reduced plasma IFN- $\gamma$ and TNF- $\alpha$ pro-inflammatory cytokines and stimulated increases in IL-4 and IL-10 anti-inflammatory cytokines in a randomized control trial study on upper respiratory tract-infected middle-aged patients [200]. Given the cytokine storm that many COVID-19 patients tend to experience, this form of regulation could be crucial. Orally administered probiotic strains contribute to the manner in which the immune response emanates from the intestine. Probiotics could limit SARS-CoV-2 invasion by boosting butyrate, a fuel for colonocytes. The immunological response, which is mediated by macrophages, dendritic cells, and the differentiation of CD8+ T lymphocytes into cytotoxic T lymphocytes in the presence of probiotics, can devastate infection-infected cells [201]. T-helper type 1 (Th1) and 
type 2 (Th2) cells are produced when probiotics stimulate CD4+ T lymphocytes. Th1 has been discovered to energize phagocytes and aid in the elimination of respiratory viruses, while Th2 induces B cells multiplication [201].

The presence of ROS is a prominent event in intestinal (colonic) inflammation. The antioxidant properties of probiotic strains can inhibit/reduce this effect and thereby increase probiotic GIT colonization $[159,202]$. The interaction between the epithelial cells and the gut microbiota is an active process that can be induced by the presence of probiotics in the production of pro-inflammatory cytokines [202]. Interleukin 12 (IL-12) can be induced after the activation of the innate immune system by some lactobacilli strains stimulating dendritic cells, naive T cells in the lamina propria of the GIT, and macrophages [154]. After the oral administration of Bifidobacterium longum MM-2 in an influenza-induced mouse model for 17 consecutive days, decreased virus titers, cell death, reduced mortality, and suppressed inflammation in the lower respiratory tract improved clinical symptoms. In addition, pro-inflammatory cytokines, such as IL-6 and TNF- $\alpha$, in the bronchoalveolar lavage fluid were noted [179]. This implies that innate immunity, particularly NK cell activation, is aided by probiotics, resulting in an anti-influenza virus impact that could be used as a preventative measure in the event of an influenza-like outbreak, such as COVID-19. In a similar study, conducted by China's National Health Commission (CNHC), subjects administered with influenza vaccinations and probiotic Bifidobacterium longum BB536 showed considerably higher NK cell activity and neutrophil bactericidal activity at week 5 after the administration of the probiotic. Although the placebo and the probiotic groups' NK cell and neutrophilic activities decreased towards the end of the study, they tended to remain marginally higher in the probiotic group than in the placebo group when subjected to continuous probiotic consumption for 14 weeks [181]. It is therefore noteworthy that probiotic treatment may serve as an immune booster to augment the immune capacity and response of the host to resist viral infection, in addition to the administration of a vaccine. The consumption of probiotics regularly lowers the risk of influenza and fever, most likely by enhancing innate immunity.

\subsection{Limitations}

The limitations of this review include the fact that there are little or insufficient clinical data to validate the potential risk of CRC patients contracting COVID-19. However, further studies providing more data in this area would clarify the possibility of a longer course of infection or a higher risk of severe infection. This would also enlighten us as to the impact of SARS-CoV-2 on CRC patients and the management of these diseases. In addition, there are currently limited data, and no direct clinical evidence, that modulating the gut microbiota has a therapeutic function in COVID-19 treatment. Probiotic supplements becoming beneficial in the event of a COVID-19 pandemic in the future is worth a trial. It is worth mentioning that more studies are required on the administration of probiotics in addition to the various vaccines against SARS-CoV-2 in order to determine whether this could improve the immunity level of an individual against COVID-19 with or without co-morbidity, particularly in a CRC patient. Given the varied nature of these diseases and immunosuppressive therapies, it is pertinent to understand the role of COVID-19 in CRC.

\section{Conclusions and Future Directions}

The use of probiotics, a low-cost, safe, and non-invasive approach, is one of the most significant therapeutic additions for humans to activate the immunity required by the body. Certain probiotic strains taken orally can help to lower the occurrence and severity of viral RTIs. Probiotics can be utilized in treatment regimens to boost immune defenses against RTIs and therefore, potentially, SARS-CoV-2 infection. According to the CNHC's guidance recommendation (Version 5), probiotics may be administered to maintain the balance of intestinal microecology and prevent subsequent bacterial infection in severe COVID-19 illnesses. This would be through the modification of the GI microbiota to improve GI symptoms while also providing respiratory protection [203]. The role of 
GI dysbiosis in COVID-19, as well as its diagnostic and prognostic value, is now being researched extensively. Unraveling the link and relationship between gut microbiota changes in COVID-19 patients, disease severity, and patients with co-morbidities such as CRC could lead to the development of a new therapeutic approach based on GI microbiota manipulation, for example, using probiotics. However, probiotics are being proposed for therapeutic trials against COVID-19 [204].

Recently, the emergence of new variants due to incessant mutation in the SARS-CoV-2 genome has caused amino acid changes in vaccine-targeted structural proteins. This has led to controversial debates over the long-term efficacy of these vaccines in protecting the host, sustaining specific resistance to re-infection, and the future need for additional vaccine boosters. Hence, it is important to understand whether the administration of vaccines alone may be sufficient to fight against SARS-CoV-2 infection. The inclusion of the administration of immune booster agents, such as probiotics, in addition to the various vaccines available, may improve the immunological protection of host cells against the virus and could be a good recommendation at this point. While none of these effects have been evaluated on the novel SARS-CoV-2, this should not disqualify this approach, especially as probiotics have been shown to have antiviral benefits against certain coronavirus strains [39]. However, further investigation is required to evaluate changes in the antibody titers to the SARS-CoV-2 vaccine and cell-mediated immunity with or without probiotics. This will improve our understanding of the impact of probiotics on the immune system in COVID-19.

Author Contributions: F.O.-A. and L.R. conceived the study. F.O.-A. performed the literature search and wrote the manuscript. F.O.-A. and L.R. contributed to the critical review of the manuscript and approval for submission. All authors have read and agreed to the published version of the manuscript.

Funding: This research was funded by the Research, Technology, Innovation, and Partnerships of Cape Peninsula University of Technology (CPUT).

Institutional Review Board Statement: Not applicable.

Informed Consent Statement: Not applicable.

Data Availability Statement: Not applicable.

Acknowledgments: The authors would like to thank the Research, Technology, Innovation, and Partnerships Department of CPUT for the support and postdoctoral opportunity.

Conflicts of Interest: The authors declare no conflict of interest.

\section{References}

1. WHO. WHO Coronavirus (COVID-19). Dashboard 2021. Available online: https:/ / covid19.who.int/ (accessed on 23 November 2021).

2. Andersen, K.G.; Rambaut, A.; Lipkin, W.I.; Holmes, E.C.; Garry, R.F. The proximal origin of SARS-CoV-2. Nat. Med. 2020, 26, 450-452. [CrossRef] [PubMed]

3. Gorbalenya, A.E.; Baker, S.C.; Baric, R.S.; de Groot, R.J.; Drosten, C.; Gulyaeva, A.A.; Haagmans, B.; Lauber, C.; Leontovich, A.; Neuman, B. Coronaviridae Study Group of the International Committee on Taxonomy of Viruses. The species severe acute respiratory syndrome-related coronavirus: Classifying 2019-nCoV and naming it SARS-CoV-2. Nat. Microbiol. 2020, 5, 536-544.

4. Lu, R.; Zhao, X.; Li, J.; Niu, P.; Yang, B.; Wu, H.; Wang, W.; Song, H.; Huang, B.; Zhu, N. Genomic characterization and epidemiology of 2019 novel coronavirus: Implications for virus origins and receptor binding. Lancet 2020, 395, 565-574. [CrossRef]

5. Chen, N.; Zhou, M.; Dong, X.; Qu, J.; Gong, F.; Han, Y.; Qiu, Y.; Wang, J.; Liu, Y.; Wei, Y. Epidemiological and clinical characteristics of 99 cases of 2019 novel coronavirus pneumonia in Wuhan, China: A descriptive study. Lancet 2020, 395, 507-513. [CrossRef]

6. Wang, D.; Hu, B.; Hu, C.; Zhu, F.; Liu, X.; Zhang, J.; Wang, B.; Xiang, H.; Cheng, Z.; Xiong, Y. Clinical characteristics of 138 hospitalized patients with 2019 novel coronavirus-infected pneumonia in Wuhan, China. JAMA 2020, 323, 1061-1069. [CrossRef]

7. Zhang, H.; Kang, Z.; Gong, H.; Xu, D.; Wang, J.; Li, Z.; Li, Z.; Cui, X.; Xiao, J.; Zhan, J. Digestive system is a potential route of COVID-19: An analysis of single-cell coexpression pattern of key proteins in the viral entry process. Gut 2020, 69, 1010-1018. [CrossRef]

8. $\quad$ Lin, L.; Jiang, X.; Zhang, Z.; Huang, S.; Zhang, Z.; Fang, Z.; Gu, Z.; Gao, L.; Shi, H.; Mai, L. Gastrointestinal symptoms of 95 cases with SARS-CoV-2 infection. Gut 2020, 69, 997-1001. [CrossRef]

9. Hikmet, F.; Méar, L.; Edvinsson, Å.; Micke, P.; Uhlén, M.; Lindskog, C. The protein expression profile of ACE2 in human tissues. Mol. Syst. Biol. 2020, 16, e9610. [CrossRef] 
10. Shang, J.; Wan, Y.; Luo, C.; Ye, G.; Geng, Q.; Auerbach, A.; Li, F. Cell entry mechanisms of SARS-CoV-2. Proc. Natl. Acad. Sci. USA 2020, 117, 11727-11734. [CrossRef]

11. Hoffmann, M.; Kleine-Weber, H.; Schroeder, S.; Krüger, N.; Herrler, T.; Erichsen, S.; Schiergens, T.S.; Herrler, G.; Wu, N.-H.; Nitsche, A. SARS-CoV-2 cell entry depends on ACE2 and TMPRSS2 and is blocked by a clinically proven protease inhibitor. Cell 2020, 181, 271-280.e278. [CrossRef]

12. Caniglia, J.L.; Asuthkar, S.; Tsung, A.J.; Guda, M.R.; Velpula, K.K. Immunopathology of galectin-3: An increasingly promising target in COVID-19. F1000Research 2020, 9, 1078. [CrossRef] [PubMed]

13. Garcia-Revilla, J.; Deierborg, T.; Venero, J.L.; Boza-Serrano, A. Hyperinflammation and fibrosis in severe COVID-19 patients: Galectin-3, a target molecule to consider. Front. Immunol. 2020, 11, 2069. [CrossRef] [PubMed]

14. Baker, A.N.; Richards, S.-J.; Guy, C.S.; Congdon, T.R.; Hasan, M.; Zwetsloot, A.J.; Gallo, A.; Lewandowski, J.R.; Stansfeld, P.J.; Straube, A. The SARS-CoV-2 spike protein binds sialic acids and enables rapid detection in a lateral flow point of care diagnostic device. ACS Cent. Sci. 2020, 6, 2046-2052. [CrossRef] [PubMed]

15. Helal, M.A.; Shouman, S.; Abdelwaly, A.; Elmehrath, A.O.; Essawy, M.; Sayed, S.M.; Saleh, A.H.; El-Badri, N. Molecular basis of the potential interaction of SARS-CoV-2 spike protein to CD147 in COVID-19 associated-lymphopenia. J. Biomol. Struct. Dyn. 2020, 1-11. [CrossRef]

16. Reyfman, P.A.; Walter, J.M.; Joshi, N.; Anekalla, K.R.; McQuattie-Pimentel, A.C.; Chiu, S.; Fernandez, R.; Akbarpour, M.; Chen, C.-I.; Ren, Z. Single-cell transcriptomic analysis of human lung provides insights into the pathobiology of pulmonary fibrosis. Am. J. Respir. Crit. Care Med. 2019, 199, 1517-1536. [CrossRef]

17. Xiao, F.; Tang, M.; Zheng, X.; Liu, Y.; Li, X.; Shan, H. Evidence for gastrointestinal infection of SARS-CoV-2. Gastroenterology 2020, 158, 1831-1833.e3. [CrossRef]

18. Zang, R.; Castro, M.F.G.; McCune, B.T.; Zeng, Q.; Rothlauf, P.W.; Sonnek, N.M.; Liu, Z.; Brulois, K.F.; Wang, X.; Greenberg, H.B. TMPRSS2 and TMPRSS4 promote SARS-CoV-2 infection of human small intestinal enterocytes. Sci. Immunol. 2020, 5, eabc3582. [CrossRef]

19. Niu, P.; Lei, F.; Gu, J. Colorectal cancer and COVID-19: Do we need to raise awareness and vigilance? Cancer 2021, 127, 979. [CrossRef]

20. Sung, H.; Ferlay, J.; Siegel, R.L.; Laversanne, M.; Soerjomataram, I.; Jemal, A.; Bray, F. Global Cancer Statistics 2020: GLOBOCAN Estimates of Incidence and Mortality Worldwide for 36 Cancers in 185 Countries. CA Cancer J. Clin. 2021, 71, 209-249. [CrossRef]

21. Gagnière, J.; Raisch, J.; Veziant, J.; Barnich, N.; Bonnet, R.; Buc, E.; Bringer, M.-A.; Pezet, D.; Bonnet, M. Gut microbiota imbalance and colorectal cancer. World J. Gastroenterol. 2016, 22, 501. [CrossRef]

22. Louis, P.; Hold, G.L.; Flint, H.J. The gut microbiota, bacterial metabolites, and colorectal cancer. Nat. Rev. Microbiol. 2014, 12, 661-672. [CrossRef]

23. Gu, S.; Chen, Y.; Wu, Z.; Chen, Y.; Gao, H.; Lv, L.; Guo, F.; Zhang, X.; Luo, R.; Huang, C. Alterations of the gut microbiota in patients with coronavirus disease 2019 or H1N1 influenza. Clin. Infect. Dis. 2020, 71, 2669-2678. [CrossRef]

24. Khatiwada, S.; Subedi, A. Lung microbiome and coronavirus disease 2019 (COVID-19): Possible link and implications. Hum. Microbiome J. 2020, 17, 100073. [CrossRef] [PubMed]

25. Zuo, T.; Zhang, F.; Lui, G.C.; Yeoh, Y.K.; Li, A.Y.; Zhan, H.; Wan, Y.; Chung, A.C.; Cheung, C.P.; Chen, N. Alterations in the gut microbiota of patients with COVID-19 during the time of hospitalization. Gastroenterology 2020, 159, 944-955. [CrossRef] [PubMed]

26. Chen, C.-C.; Lin, W.-C.; Kong, M.-S.; Shi, H.N.; Walker, W.A.; Lin, C.-Y.; Huang, C.-T.; Lin, Y.-C.; Jung, S.-M.; Lin, T.-Y. Oral inoculation of probiotics Lactobacillus acidophilus NCFM suppresses tumor growth both in segmental orthotopic colon cancer and extra-intestinal tissue. Br. J. Nutr. 2012, 107, 1623-1634. [CrossRef] [PubMed]

27. Gao, Z.; Guo, B.; Gao, R.; Zhu, Q.; Qin, H. Microbiota dysbiosis is associated with colorectal cancer. Front. Microbiol. 2015, 6, 20. [CrossRef]

28. Beech, A.S.; Lea, S.; Kolsum, U.; Wang, Z.; Miller, B.E.; Donaldson, G.C.; Wedzicha, J.A.; Brightling, C.E.; Singh, D. Bacteria and sputum inflammatory cell counts; a COPD cohort analysis. Respir. Res. 2020, 21, 289. [CrossRef] [PubMed]

29. Edouard, S.; Million, M.; Bachar, D.; Dubourg, G.; Michelle, C.; Ninove, L.; Charrel, R.; Raoult, D. The nasopharyngeal microbiota in patients with viral respiratory tract infections is enriched in bacterial pathogens. Eur. J. Clin. Microbiol. Infect. Dis. 2018, 37, 1725-1733. [CrossRef]

30. Man, W.H.; van Houten, M.A.; Mérelle, M.E.; Vlieger, A.M.; Chu, M.L.J.; Jansen, N.J.; Sanders, E.A.; Bogaert, D. Bacterial and viral respiratory tract microbiota and host characteristics in children with lower respiratory tract infections: A matched case-control study. Lancet Respir. Med. 2019, 7, 417-426. [CrossRef]

31. Zuo, T.; Zhan, H.; Zhang, F.; Liu, Q.; Tso, E.Y.; Lui, G.C.; Chen, N.; Li, A.; Lu, W.; Chan, F.K. Alterations in the fecal fungal microbiome of patients with COVID-19 during the time of hospitalization until discharge. Gastroenterology 2020, 159, 1302-1310. [CrossRef] [PubMed]

32. Ahlawat, S.; Sharma, K.K. Immunological coordination between gut and lungs in SARS-CoV-2 infection. Virus Res. 2020, 286, 198103. [CrossRef] [PubMed]

33. AKTAŞ, B.; Aslim, B. Gut-lung axis and dysbiosis in COVID-19. Turk. J. Biol. 2020, 44, 265-272. [CrossRef] [PubMed]

34. Din, A.U.; Mazhar, M.; Waseem, M.; Ahmad, W.; Bibi, A.; Hassan, A.; Ali, N.; Gang, W.; Qian, G.; Ullah, R. SARS-CoV-2 microbiome dysbiosis linked disorders and possible probiotics role. Biomed. Pharmacother. 2021, 133, 110947. [CrossRef] [PubMed] 
35. Hill, C.; Guarner, F.; Reid, G.; Gibson, G.R.; Merenstein, D.J.; Pot, B.; Morelli, L.; Canani, R.B.; Flint, H.J.; Salminen, S. Expert consensus document: The International Scientific Association for Probiotics and Prebiotics consensus statement on the scope and appropriate use of the term probiotic. Nat. Rev. Gastroenterol. Hepatol. 2014, 11, 506-514. [CrossRef] [PubMed]

36. Hotel, A.C.P.; Cordoba, A. Health and nutritional properties of probiotics in food including powder milk with live lactic acid bacteria. Prevention 2001, 5, 1-10.

37. Vasiljevic, T.; Shah, N.P. Probiotics—from Metchnikoff to bioactive. Int. Dairy J. 2008, 18, 714-728. [CrossRef]

38. Sanders, M.E.; Gibson, G.; Gill, H.S.; Guarner, F. Probiotics: Their potential to impact human health. Counc. Agric. Sci. Technol. Issue Pap. 2007, 36, 1-20.

39. Baud, D.; Dimopoulou Agri, V.; Gibson, G.R.; Reid, G.; Giannoni, E. Using probiotics to flatten the curve of coronavirus disease COVID-2019 pandemic. Front. Public Health 2020, 8, 186. [CrossRef]

40. Lenoir-Wijnkoop, I.; Gerlier, L.; Roy, D.; Reid, G. The clinical and economic impact of probiotics consumption on respiratory tract infections: Projections for Canada. PLoS ONE 2016, 11, e0166232. [CrossRef]

41. Szajewska, H.; Kołodziej, M.; Gieruszczak-Białek, D.; Skórka, A.; Ruszczyński, M.; Shamir, R. Systematic review with metaanalysis: Lactobacillus rhamnosus GG for treating acute gastroenteritis in children-A 2019 update. Aliment. Pharmacol. Ther. 2019, 49, 1376-1384. [CrossRef]

42. Guillemard, E.; Tondu, F.; Lacoin, F.; Schrezenmeir, J. Consumption of a fermented dairy product containing the probiotic Lactobacillus casei DN-114 001 reduces the duration of respiratory infections in the elderly in a randomized controlled trial. Br. J. Nutr. 2010, 103, 58-68. [CrossRef] [PubMed]

43. Manna, S.; Chowdhury, T.; Chakraborty, R.; Mandal, S.M. Probiotics-derived peptides and their immunomodulatory molecules can play a preventive role against viral diseases including COVID-19. Probiotics Antimicrob. Proteins 2021, 13, 611-623. [CrossRef] [PubMed]

44. Power, D.; Burton, J.; Chilcott, C.; Dawes, P.; Tagg, J. Preliminary investigations of the colonization of upper respiratory tract tissues of infants using a pediatric formulation of the oral probiotic Streptococcus salivarius K12. Eur. J. Clin. Microbiol. Infect. Dis. 2008, 27, 1261-1263. [CrossRef] [PubMed]

45. Weiss, G.; Rasmussen, S.; Zeuthen, L.H.; Nielsen, B.N.; Jarmer, H.; Jespersen, L.; Frøkiær, H. Lactobacillus acidophilus induces virus immune defense genes in murine dendritic cells by a Toll-like receptor-2-dependent mechanism. Immunology 2010, 131, 268-281. [CrossRef] [PubMed]

46. Lehtoranta, L.; Kalima, K.; He, L.; Lappalainen, M.; Roivainen, M.; Närkiö, M.; Mäkelä, M.; Siitonen, S.; Korpela, R.; Pitkäranta, A. Specific probiotics and virological findings in symptomatic conscripts attending military service in Finland. J. Clin. Virol. 2014, 60, 276-281. [CrossRef]

47. Hendler, R.; Zhang, Y. Probiotics in the treatment of colorectal cancer. Medicines 2018, 5, 101. [CrossRef]

48. Meng, C.; Bai, C.; Brown, T.D.; Hood, L.E.; Tian, Q. Human gut microbiota and gastrointestinal cancer. Genom. Proteom. Bioinform. 2018, 16, 33-49. [CrossRef]

49. Raskov, H.; Burcharth, J.; Pommergaard, H.-C. Linking gut microbiota to colorectal cancer. J. Cancer 2017, 8, 3378. [CrossRef]

50. Sender, R.; Fuchs, S.; Milo, R. Are we really vastly outnumbered? Revisiting the ratio of bacterial to host cells in humans. Cell 2016, 164, 337-340. [CrossRef]

51. Boleij, A.; Tjalsma, H. Gut bacteria in health and disease: A survey on the interface between intestinal microbiology and colorectal cancer. Biol. Rev. 2012, 87, 701-730. [CrossRef]

52. Aureli, P.; Capurso, L.; Castellazzi, A.M.; Clerici, M.; Giovannini, M.; Morelli, L.; Poli, A.; Pregliasco, F.; Salvini, F.; Zuccotti, G.V. Probiotics and health: An evidence-based review. Pharmacol. Res. 2011, 63, 366-376. [CrossRef] [PubMed]

53. Claesson, M.J.; Cusack, S.; O'Sullivan, O.; Greene-Diniz, R.; de Weerd, H.; Flannery, E.; Marchesi, J.R.; Falush, D.; Dinan, T.; Fitzgerald, G. Composition, variability, and temporal stability of the intestinal microbiota of the elderly. Proc. Natl. Acad. Sci. USA 2011, 108 (Suppl. S1), 4586-4591. [CrossRef]

54. Marchesi, J.R. Human distal gut microbiome. Environ. Microbiol. 2011, 13, 3088-3102. [CrossRef] [PubMed]

55. Hakansson, A.; Molin, G. Gut microbiota and inflammation. Nutrients 2011, 3, 637-682. [CrossRef] [PubMed]

56. Sekirov, I.; Russell, S.L.; Antunes, L.C.M.; Finlay, B.B. Gut microbiota in health and disease. Physiol. Rev. 2010, 90, 859-904. [CrossRef]

57. Quigley, E.M.M. Gut microbiota and the role of probiotics in therapy. Curr. Opin. Pharmacol. 2011, 11, 593-603. [CrossRef]

58. Swidsinski, A.; Weber, J.; Loening-Baucke, V.; Hale, L.P.; Lochs, H. Spatial organization, and composition of the mucosal flora in patients with inflammatory bowel disease. J. Clin. Microbiol. 2005, 43, 3380-3389. [CrossRef]

59. Quigley, E.M.; Abu-Shanab, A. Small intestinal bacterial overgrowth. Infect. Dis. Clin. 2010, 24, 943-959. [CrossRef]

60. Srikanth, C.; McCormick, B.A. Interactions of the intestinal epithelium with the pathogen and the indigenous microbiota: A three-way crosstalk. Interdiscip. Perspect. Infect. Dis. 2008, 2008, 626827. [CrossRef]

61. Castellarin, M.; Warren, R.L.; Freeman, J.D.; Dreolini, L.; Krzywinski, M.; Strauss, J.; Barnes, R.; Watson, P.; Allen-Vercoe, E.; Moore, R.A. Fusobacterium nucleatum infection is prevalent in human colorectal carcinoma. Genome Res. 2012, 22, 299-306. [CrossRef]

62. Marchesi, J.R.; Dutilh, B.E.; Hall, N.; Peters, W.H.; Roelofs, R.; Boleij, A.; Tjalsma, H. Towards the human colorectal cancer microbiome. PLoS ONE 2011, 6, e20447. [CrossRef] [PubMed] 
63. Sobhani, I.; Tap, J.; Roudot-Thoraval, F.; Roperch, J.P.; Letulle, S.; Langella, P.; Corthier, G.; Van Nhieu, J.T.; Furet, J.P. Microbial dysbiosis in colorectal cancer (CRC) patients. PLoS ONE 2011, 6, e16393. [CrossRef] [PubMed]

64. Ray, K. Fusobacterium nucleatum found in colon cancer tissue-Could an infection cause colorectal cancer? Nat. Rev. Gastroenterol. Hepatol. 2011, 8, 662. [CrossRef] [PubMed]

65. Strauss, J.; Kaplan, G.G.; Beck, P.L.; Rioux, K.; Panaccione, R.; DeVinney, R.; Lynch, T.; Allen-Vercoe, E. Invasive potential of gut mucosa-derived Fusobacterium nucleatum positively correlates with IBD status of the host. Inflamm. Bowel Dis. 2011, 17, 1971-1978. [CrossRef]

66. Flynn, K.J.; Baxter, N.T.; Schloss, P.D. Metabolic and community synergy of oral bacteria in colorectal cancer. Msphere 2016, 1, e00102-e00116. [CrossRef] [PubMed]

67. Kostic, A.D.; Chun, E.; Robertson, L.; Glickman, J.N.; Gallini, C.A.; Michaud, M.; Clancy, T.E.; Chung, D.C.; Lochhead, P.; Hold, G.L. Fusobacterium nucleatum potentiates intestinal tumorigenesis and modulates the tumor-immune microenvironment. Cell Host Microbe 2013, 14, 207-215. [CrossRef] [PubMed]

68. Hirayama, A.; Kami, K.; Sugimoto, M.; Sugawara, M.; Toki, N.; Onozuka, H.; Kinoshita, T.; Saito, N.; Ochiai, A.; Tomita, M. Quantitative metabolome profiling of colon and stomach cancer microenvironment by capillary electrophoresis time-of-flight mass spectrometry. Cancer Res. 2009, 69, 4918-4925. [CrossRef]

69. Tjalsma, H.; Boleij, A.; Marchesi, J.R.; Dutilh, B.E. A bacterial driver-passenger model for colorectal cancer: Beyond the usual suspects. Nat. Rev. Microbiol. 2012, 10, 575-582. [CrossRef] [PubMed]

70. Sears, C.L.; Garrett, W.S. Microbes, microbiota, and colon cancer. Cell Host Microbe 2014, 15, 317-328. [CrossRef] [PubMed]

71. Uronis, J.M.; Mühlbauer, M.; Herfarth, H.H.; Rubinas, T.C.; Jones, G.S.; Jobin, C. Modulation of the intestinal microbiota alters colitis-associated colorectal cancer susceptibility. PLoS ONE 2009, 4, e6026. [CrossRef]

72. Wang, X.; Allen, T.D.; May, R.J.; Lightfoot, S.; Houchen, C.W.; Huycke, M.M. Enterococcus faecalis induces aneuploidy and tetraploidy in colonic epithelial cells through a bystander effect. Cancer Res. 2008, 68, 9909-9917. [CrossRef] [PubMed]

73. Advani, S.M.; Advani, P.S.; Brown, D.W.; DeSantis, S.M.; Korphaisarn, K.; VonVille, H.M.; Bressler, J.; Lopez, D.S.; Davis, J.S.; Daniel, C.R. Global differences in the prevalence of the CpG island methylator phenotype of colorectal cancer. BMC Cancer 2019, 19, 964. [CrossRef]

74. Cheriyamundath, S.; Ben-Ze'ev, A. Wnt/ $\beta$-Catenin target genes in colon cancer metastasis: The special case of L1cam. Cancers 2020, 12, 3444. [CrossRef] [PubMed]

75. McCrea, P.D.; Gottardi, C.J. Beyond $\beta$-catenin: Prospects for a larger catenin network in the nucleus. Nat. Rev. Mol. Cell Biol. 2016, 17, 55-64. [CrossRef] [PubMed]

76. Boland, C.R.; Goel, A. Microsatellite instability in colorectal cancer. Gastroenterology 2010, 138, 2073-2087. [CrossRef] [PubMed]

77. Arthur, J.C.; Gharaibeh, R.Z.; Mühlbauer, M.; Perez-Chanona, E.; Uronis, J.M.; McCafferty, J.; Fodor, A.A.; Jobin, C. Microbial genomic analysis reveals the essential role of inflammation in bacteria-induced colorectal cancer. Nat. Commun. 2014, 5, 4724. [CrossRef]

78. Enaud, R.; Prevel, R.; Ciarlo, E.; Beaufils, F.; Wieërs, G.; Guery, B.; Delhaes, L. The gut-lung axis in health and respiratory diseases: A place for inter-organ and inter-kingdom crosstalks. Front. Cell. Infect. Microbiol. 2020, 10, 9. [CrossRef]

79. Mulak, A. The impact of probiotics on interactions within the microbiota-gut-lung triad in COVID-19. Int. J. Food Sci. Nutr. 2021, 72, 577-578. [CrossRef]

80. Zuo, T.; Liu, Q.; Zhang, F.; Lui, G.C.-Y.; Tso, E.Y.; Yeoh, Y.K.; Chen, Z.; Boon, S.S.; Chan, F.K.; Chan, P.K. Depicting SARS-CoV-2 fecal viral activity in association with gut microbiota composition in patients with COVID-19. Gut 2021, 70, $276-284$.

81. Viana, S.D.; Nunes, S.; Reis, F. ACE2 imbalance as a key player for the poor outcomes in COVID-19 patients with age-related comorbidities-Role of gut microbiota dysbiosis. Ageing Res. Rev. 2020, 62, 101123. [CrossRef]

82. Mönkemüller, K.; Fry, L.C.; Rickes, S. Systemic inflammatory response and thrombosis due to alterations in the gut microbiota in COVID-19. Rev. Esp. Enferm. Dig. Organo Of. Soc. Esp. Patol. Dig. 2020, 112, 584-585.

83. Tang, L.; Gu, S.; Gong, Y.; Li, B.; Lu, H.; Li, Q.; Zhang, R.; Gao, X.; Wu, Z.; Zhang, J. Clinical significance of the correlation between changes in the major intestinal bacteria species and COVID-19 severity. Engineering 2020, 6, 1178-1184. [CrossRef]

84. Dhar, D.; Mohanty, A. Gut microbiota and COVID-19-Possible link and implications. Virus Res. 2020, 285, 198018. [CrossRef] [PubMed]

85. Gou, W.; Fu, Y.; Yue, L.; Chen, G.-d.; Cai, X.; Shuai, M.; Xu, F.; Yi, X.; Chen, H.; Zhu, Y.J. Gut microbiota may underlie the predisposition of healthy individuals to COVID-19. medRxiv 2020. [CrossRef]

86. Brown, A.; Fernández, I.S.; Gordiyenko, Y.; Ramakrishnan, V. Ribosome-dependent activation of stringent control. Nature 2016, 534, 277-280. [CrossRef]

87. Brown, M.V.; Reader, J.S.; Tzima, E. Mammalian aminoacyl-tRNA synthetases: Cell signaling functions of the protein translation machinery. Vasc. Pharmacol. 2010, 52, 21-26. [CrossRef]

88. Kim, Y.; Sundrud, M.S.; Zhou, C.; Edenius, M.; Zocco, D.; Powers, K.; Zhang, M.; Mazitschek, R.; Rao, A.; Yeo, C.-Y. AminoacyltRNA synthetase inhibition activates a pathway that branches from the canonical amino acid response in mammalian cells. Proc. Natl. Acad. Sci. USA 2020, 117, 8900-8911. [CrossRef]

89. Zhang, S.; Zeng, X.; Ren, M.; Mao, X.; Qiao, S. Novel metabolic and physiological functions of branched-chain amino acids: A review. J. Anim. Sci. Biotechnol. 2017, 8, 10. [CrossRef] 
90. Bao, R.; Hernandez, K.; Huang, L.; Luke, J.J. ACE2 and TMPRSS2 expression by clinical, HLA, immune, and microbial correlates across 34 human cancers and matched normal tissues: Implications for SARS-CoV-2 COVID-19. J. Immunother. Cancer 2020, 8, e001020. [CrossRef]

91. Lamers, M.M.; Beumer, J.; van der Vaart, J.; Knoops, K.; Puschhof, J.; Breugem, T.I.; Ravelli, R.B.; Van Schayck, J.P.; Mykytyn, A.Z.; Duimel, H.Q. SARS-CoV-2 productively infects human gut enterocytes. Science 2020, 369, 50-54. [CrossRef]

92. Liu, C.; Wang, K.; Zhang, M.; Hu, X.; Hu, T.; Liu, Y.; Hu, Q.; Wu, S.; Yue, J. High expression of ACE2 and TMPRSS2 and clinical characteristics of COVID-19 in colorectal cancer patients. NPJ Precis. Oncol. 2021, 5, 1. [CrossRef] [PubMed]

93. Zhang, H.; Li, H.-B.; Lyu, J.-R.; Lei, X.-M.; Li, W.; Wu, G.; Lyu, J.; Dai, Z.-M. Specific ACE2 expression in small intestinal enterocytes may cause gastrointestinal symptoms and injury after 2019-nCoV infection. Int. J. Infect. Dis. 2020, 96, 19-24. [CrossRef] [PubMed]

94. Wu, Q.; Zhang, H.; Zhong, Y.; Chua, M.L.K.; Xie, C. Reply to colorectal cancer and COVID-19: Do we need to raise awareness and vigilance? Cancer 2021, 127, 980-981. [CrossRef] [PubMed]

95. Deriu, E.; Boxx, G.M.; He, X.; Pan, C.; Benavidez, S.D.; Cen, L.; Rozengurt, N.; Shi, W.; Cheng, G. Influenza virus affects intestinal microbiota and secondary Salmonella infection in the gut through type I Interferons. PLoS Pathog. 2016, 12, e1005572. [CrossRef]

96. Zha, L.; Garrett, S.; Sun, J. Salmonella infection in chronic inflammation and gastrointestinal cancer. Diseases 2019, 7, 28. [CrossRef]

97. Ma, W.-T.; Yao, X.-T.; Peng, Q.; Chen, D.-K. The protective and pathogenic roles of IL-17 in viral infections: Friend or foe? Open Biol. 2019, 9, 190109. [CrossRef]

98. Wang, X.; Ma, K.; Chen, M.; Ko, K.-H.; Zheng, B.-J.; Lu, L. IL-17A Promotes Pulmonary B-1a Cell Differentiation via Induction of Blimp-1 Expression during Influenza Virus Infection. PLoS Pathog. 2016, 12, e1005367. [CrossRef]

99. Ivanov, I.I.; de Llanos Frutos, R.; Manel, N.; Yoshinaga, K.; Rifkin, D.B.; Sartor, R.B.; Finlay, B.B.; Littman, D.R. Specific microbiota direct the differentiation of IL-17-producing T-helper cells in the mucosa of the small intestine. Cell Host. Microb. 2008, 4, 337-349. [CrossRef]

100. Mazmanian, S.K.; Round, J.L.; Kasper, D.L. A microbial symbiosis factor prevents intestinal inflammatory disease. Nature 2008, 453, 620-625. [CrossRef]

101. Sobhani, I.; Le Gouvello, S. Critical role for CD8+ FoxP3+ regulatory T cells in colon cancer immune response in humans. Gut 2009, 58, 743-744. [CrossRef]

102. Wu, S.; Rhee, K.-J.; Albesiano, E.; Rabizadeh, S.; Wu, X.; Yen, H.-R.; Huso, D.L.; Brancati, F.L.; Wick, E.; McAllister, F. A human colonic commensal promotes colon tumorigenesis via activation of T helper type 17 T cell responses. Nat. Med. 2009, 15, 1016-1022. [CrossRef]

103. van Dam, P.A.; Huizing, M.; Mestach, G.; Dierckxsens, S.; Tjalma, W.; Trinh, X.B.; Papadimitriou, K.; Altintas, S.; Vermorken, J.; Vulsteke, C.; et al. SARS-CoV-2 and cancer: Are they really partners in crime? Cancer Treat. Rev. 2020, 89, 102068. [CrossRef]

104. McGill, A.R.; Kahlil, R.; Dutta, R.; Green, R.; Howell, M.; Mohapatra, S.; Mohapatra, S.S. SARS-CoV-2 Immuno-pathogenesis and potential for diverse vaccines and therapies: Opportunities and challenges. Infect. Dis. Rep. 2021, 13, 102-125. [CrossRef] [PubMed]

105. Howell, M.C.; Green, R.; McGill, A.R.; Dutta, R.; Mohapatra, S.; Mohapatra, S.S. SARS-CoV-2-Induced Gut Microbiome Dysbiosis: Implications for Colorectal Cancer. Cancers 2021, 13, 2676. [CrossRef] [PubMed]

106. Vandenplas, Y.; Salvatore, S.; Viera, M.; Devreker, T.; Hauser, B. Probiotics in infectious diarrhea in children: Are they indicated? Eur. J. Pediatr. 2007, 166, 1211-1218. [CrossRef] [PubMed]

107. Meurman, J.H.; Stamatova, I. Probiotics: Contributions to oral health. Oral Dis. 2007, 13, 443-451. [CrossRef]

108. Canani, R.B.; Cirillo, P.; Terrin, G.; Cesarano, L.; Spagnuolo, M.I.; De Vincenzo, A.; Albano, F.; Passariello, A.; De Marco, G.; Manguso, F. Probiotics for treatment of acute diarrhea in children: A randomized clinical trial of five different preparations. BMJ 2007, 335, 340. [CrossRef]

109. Krasaekoopt, W.; Bhandari, B.; Deeth, H. Evaluation of encapsulation techniques of probiotics for yogurt. Int. Dairy J. 2003, 13, 3-13. [CrossRef]

110. Food and Agriculture Organisation. WHO Working Group Report on Drafting Guidelines for the Evaluation of Probiotics in Food; Food and Agriculture Organization of the United Nations, World Health Organization: London, ON, Canada, 2002; p. 30.

111. Quigley, E.M. Gut bacteria in health and disease. Gastroenterol. Hepatol. 2013, 9, 560.

112. Saad, N.; Delattre, C.; Urdaci, M.; Schmitter, J.-M.; Bressollier, P. An overview of the last advances in the probiotic and prebiotic field. LWT Food. Sci. Technol. 2013, 50, 1-16. [CrossRef]

113. Baldwin, C.; Millette, M.; Oth, D.; Ruiz, M.T.; Luquet, F.-M.; Lacroix, M. Probiotic Lactobacillus acidophilus and Lactobacillus casei mix sensitize colorectal tumoral cells to 5-fluorouracil-induced apoptosis. Nutr. Cancer 2010, 62, 371-378. [CrossRef]

114. An, J.; Ha, E.-M. Combination therapy of Lactobacillus plantarum supernatant and 5-fluouracil increases chemosensitivity in colorectal cancer cells. J. Microbiol. Biotechnol. 2016, 26, 1490-1503. [CrossRef]

115. Escamilla, J.; Lane, M.A.; Maitin, V. Cell-free supernatants from probiotic Lactobacillus casei and Lactobacillus rhamnosus GG decrease colon cancer cell invasion in vitro. Nutr. Cancer 2012, 64, 871-878. [CrossRef] [PubMed]

116. Dallal, M.M.S.; Mojarrad, M.; Baghbani, F.; Raoofian, R.; Mardaneh, J.; Salehipour, Z. Effects of probiotic Lactobacillus acidophilus and Lactobacillus casei on colorectal tumor cells activity (CaCo-2). Arch. Iran. Med. 2015, 18, 167-172. 
117. Cousin, F.J.; Jouan-Lanhouet, S.; Théret, N.; Brenner, C.; Jouan, E.; Le Moigne-Muller, G.; Dimanche-Boitrel, M.-T.; Jan, G. The probiotic Propionibacterium freudenreichii as a new adjuvant for TRAIL-based therapy in colorectal cancer. Oncotarget 2016, 7, 7161. [CrossRef] [PubMed]

118. Chen, Z.-Y.; Hsieh, Y.-M.; Huang, C.-C.; Tsai, C.-C. Inhibitory effects of probiotic Lactobacillus on the growth of human colonic carcinoma cell line HT-29. Molecules 2017, 22, 107. [CrossRef]

119. Kahouli, I.; Malhotra, M.; Westfall, S.; Alaoui-Jamali, M.A.; Prakash, S. Design and validation of an orally administrated active L. fermentum-L. acidophilus probiotic formulation using colorectal cancer Apc Min/+ mouse model. Appl. Microbiol. Biotechnol. 2017, 101, 1999-2019. [CrossRef]

120. Appleyard, C.B.; Cruz, M.L.; Isidro, A.A.; Arthur, J.C.; Jobin, C.; De Simone, C. Pretreatment with the probiotic VSL\# 3 delays transition from inflammation to dysplasia in a rat model of colitis-associated cancer. Am. J. Physiol. Gastrointest. 2011, 301, G1004-G1013.

121. Yan, F.; Cao, H.; Cover, T.L.; Washington, M.K.; Shi, Y.; Liu, L.; Chaturvedi, R.; Peek, R.M.; Wilson, K.T.; Polk, D.B. Colonspecific delivery of a probiotic-derived soluble protein ameliorates intestinal inflammation in mice through an EGFR-dependent mechanism. J. Clin. Investig. 2011, 121, 2242-2253. [CrossRef]

122. Hu, J.; Wang, C.; Ye, L.; Yang, W.; Huang, H.; Meng, F.; Shi, S.; Ding, Z. Anti-tumour immune effect of oral administration of Lactobacillus plantarum to CT26 tumor-bearing mice. J. Biosci. 2015, 40, 269-279. [CrossRef]

123. Odun-Ayo, F.; Mellem, J.; Reddy, L. Improving the survival of probiotics in simulated conditions and azoxymethane-induced colon tumor-bearing mice using modified citrus pectin-alginate microencapsulation. Afr. J. Tradit. Complement. Altern. Med. 2016, 13, 101-109. [CrossRef]

124. Odun-Ayo, F.; Mellem, J.; Reddy, L. The effect of modified citrus pectin-probiotic on fecal Lactobacilli in Balb/c mice. Food. Sci. Technol. 2017, 37, 478-482. [CrossRef]

125. Song, H.; Wang, W.; Shen, B.; Jia, H.; Hou, Z.; Chen, P.; Sun, Y. Pretreatment with probiotic Bifico ameliorates colitis-associated cancer in mice: Transcriptome and gut flora profiling. Cancer Sci. 2018, 109, 666-677. [CrossRef] [PubMed]

126. Heydari, Z.; Rahaie, M.; Alizadeh, A.M.; Agah, S.; Khalighfard, S.; Bahmani, S. Effects of Lactobacillus acidophilus and Bifidobacterium bifidum probiotics on the expression of microRNAs 135b, 26b, 18a and 155, and their involving genes in mice colon cancer. Probiotics Antimicrob. 2019, 11, 1155-1162. [CrossRef]

127. Mego, M.; Chovanec, J.; Vochyanova-Andrezalova, I.; Konkolovsky, P.; Mikulova, M.; Reckova, M.; Miskovska, V.; Bystricky, B.; Beniak, J.; Medvecova, L. Prevention of irinotecan induced diarrhea by probiotics: A randomized double blind, placebo controlled pilot study. Complement. Ther. Med. 2015, 23, 356-362. [CrossRef] [PubMed]

128. Kotzampassi, K.; Stavrou, G.; Damoraki, G.; Georgitsi, M.; Basdanis, G.; Tsaousi, G.; Giamarellos-Bourboulis, E.J. A four-probiotics regimen reduces postoperative complications after colorectal surgery: A randomized, double-blind, placebo-controlled study. World J. Surg. 2015, 39, 2776-2783. [CrossRef]

129. Theodoropoulos, G.E.; Memos, N.A.; Peitsidou, K.; Karantanos, T.; Spyropoulos, B.G.; Zografos, G. Synbiotics and gastrointestinal function-related quality of life after elective colorectal cancer resection. Ann. Gastroenterol. 2016, 29, 56. [PubMed]

130. Hibberd, A.A.; Lyra, A.; Ouwehand, A.C.; Rolny, P.; Lindegren, H.; Cedgård, L.; Wettergren, Y. Intestinal microbiota is altered in patients with colon cancer and modified by probiotic intervention. BMJ Open Gastroenterol. 2017, 4, e000145. [CrossRef]

131. Kahouli, I.; Tomaro-Duchesneau, C.; Prakash, S. Probiotics in colorectal cancer (CRC) with emphasis on mechanisms of action and current perspectives. J. Med. Microbiol. 2013, 62, 1107-1123. [CrossRef]

132. Malago, J.J.; Tooten, P.C.; Koninkx, J.F. Anti-inflammatory properties of probiotic bacteria on Salmonella-induced IL-8 synthesis in enterocyte-like Caco-2 cells. Benef. Microbes 2010, 1, 121-130. [CrossRef]

133. Odun-Ayo, F.; Mellem, J.; Naicker, T.; Reddy, L. Chemoprevention of azoxymethane-induced colonic carcinogenesis in Balb/c mice using a modified pectin alginate probiotic. Anticancer Res. 2015, 35, 4765-4775.

134. Liu, D.; Jiang, X.-Y.; Zhou, L.-S.; Song, J.-H.; Zhang, X. Effects of probiotics on intestinal mucosa barrier in patients with colorectal cancer after operation: A meta-analysis of randomized controlled trials. Medicine 2016, 95, e3342. [CrossRef] [PubMed]

135. Arora, T.; Singh, S.; Sharma, R.K. Probiotics: Interaction with gut microbiome and antiobesity potential. Nutrition 2013, 29 , 591-596. [CrossRef] [PubMed]

136. Gholizadeh, P.; Mahallei, M.; Pormohammad, A.; Varshochi, M.; Ganbarov, K.; Zeinalzadeh, E.; Yousefi, B.; Bastami, M.; Tanomand, A.; Mahmood, S.S. Microbial balance in the intestinal microbiota and its association with diabetes, obesity and allergic disease. Microb. Pathog. 2019, 127, 48-55. [CrossRef] [PubMed]

137. Gregoret, V.; Perezlindo, M.; Vinderola, G.; Reinheimer, J.; Binetti, A. A comprehensive approach to determine the probiotic potential of human-derived Lactobacillus for industrial use. Food Microbiol. 2013, 34, 19-28. [CrossRef] [PubMed]

138. Yadav, H.; Jain, S.; Yadav, M. Probiotics and Diabetes/Obesity. In Bioactive Food as Dietary Interventions for Diabetes; Academic Press: Cambridge, MA, USA, 2012; pp. 307-317.

139. Fernandez, E.M.; Valenti, V.; Rockel, C.; Hermann, C.; Pot, B.; Boneca, I.G.; Grangette, C. Anti-inflammatory capacity of selected lactobacilli in experimental colitis is driven by NOD2-mediated recognition of a specific peptidoglycan-derived muropeptide. Gut 2011, 60, 1050-1059. [CrossRef]

140. Doherty, G.; Bennett, G.; Cheifetz, A.; Moss, A. Meta-analysis: Targeting the intestinal microbiota in prophylaxis for postoperative Crohn's disease. Aliment. Pharmacol. Ther. 2010, 31, 802-809. [CrossRef] 
141. Niedzielin, K.; Kordecki, H.; ena Birkenfeld, B. A controlled, double-blind, randomized study on the efficacy of Lactobacillus plantarum $299 \mathrm{~V}$ in patients with irritable bowel syndrome. Eur. J. Gastroenterol. Hepatol. 2001, 13, 1143-1147. [CrossRef]

142. Kajander, K.; Myllyluoma, E.; Rajilić-Stojanović, M.; Kyrönpalo, S.; Rasmussen, M.; Järvenpää, S.; Zoetendal, E.G.; de Vos, W.M.; Vapaatalo, H.; Korpela, R. Clinical trial: Multispecies probiotic supplementation alleviates the symptoms of irritable bowel syndrome and stabilizes intestinal microbiota. Aliment. Pharmacol. Ther. 2008, 27, 48-57. [CrossRef]

143. McFarland, L.V.; Dublin, S. Meta-analysis of probiotics for the treatment of irritable bowel syndrome. World J. Gastroenterol. 2008, 14, 2650. [CrossRef]

144. Fernandez-Duarte, K.P.; Olaya-Galán, N.N.; Salas-Cárdenas, S.P.; Lopez-Rozo, J.; Gutierrez-Fernandez, M.F. Bifidobacterium adolescentis (DSM 20083) and Lactobacillus casei (Lafti L26-DSL): Probiotics able to block the in vitro adherence of rotavirus in MA104 cells. Probiotics Antimicrob. 2018, 10, 56-63. [CrossRef]

145. Lee, D.K.; Park, J.E.; Kim, M.J.; Seo, J.G.; Lee, J.H.; Ha, N.J. Probiotic bacteria, B. longum, and L. acidophilus inhibit infection by rotavirus in vitro and decrease the duration of diarrhea in pediatric patients. Clin. Res. Hepatol. Gastroenterol. 2015, 39, 237-244. [CrossRef] [PubMed]

146. Olaya Galán, N.; Ulloa Rubiano, J.; Velez Reyes, F.; Fernandez Duarte, K.; Salas Cardenas, S.; Gutierrez Fernandez, M. In vitro antiviral activity of Lactobacillus casei and Bifidobacterium adolescentis against rotavirus infection monitored by NSP 4 protein production. J. Appl. Microbiol. 2016, 120, 1041-1051. [CrossRef] [PubMed]

147. Hojsak, I.; Abdović, S.; Szajewska, H.; Milošević, M.; Krznarić, Ž.; Kolaček, S. Lactobacillus rhamnosus GG in the prevention of nosocomial gastrointestinal and respiratory tract infections. Pediatrics 2010, 125, e1171-e1177. [CrossRef] [PubMed]

148. Preidis, G.A.; Hill, C.; Guerrant, R.L.; Ramakrishna, B.; Tannock, G.W.; Versalovic, J. Probiotics, enteric and diarrheal diseases, and global health. Gastroenterology 2011, 140, 8-14. [CrossRef] [PubMed]

149. Sarker, S.A.; Sultana, S.; Fuchs, G.J.; Alam, N.H.; Azim, T.; Brüssow, H.; Hammarström, L. Lactobacillus paracasei strain ST11 has no effect on rotavirus but ameliorates the outcome of nonrotavirus diarrhea in children from Bangladesh. Pediatrics 2005, 116, e221-e228. [CrossRef]

150. Turnbaugh, P.J.; Bäckhed, F.; Fulton, L.; Gordon, J.I. Diet-induced obesity is linked to marked but reversible alterations in the mouse distal gut microbiome. Cell Host Microbe 2008, 3, 213-223. [CrossRef]

151. Kadooka, Y.; Sato, M.; Imaizumi, K.; Ogawa, A.; Ikuyama, K.; Akai, Y.; Okano, M.; Kagoshima, M.; Tsuchida, T. Regulation of abdominal adiposity by probiotics (Lactobacillus gasseri SBT2055) in adults with obese tendencies in a randomized controlled trial. Eur. J. Clin. Nutr. 2010, 64, 636-643. [CrossRef]

152. Rafter, J. Probiotics and colon cancer. Best Pract. Res. Clin. Gastroenterol. 2003, 17, 849-859. [CrossRef]

153. Sivamaruthi, B.S.; Kesika, P.; Chaiyasut, C. The role of probiotics in colorectal cancer management. Evid. Based Complement. Alternat. Med. 2020, 2020, 3535982. [CrossRef]

154. Zhu, Y.; Luo, T.M.; Jobin, C.; Young, H.A. Gut microbiota and probiotics in colon tumorigenesis. Cancer Lett. 2011, 309, 119-127. [CrossRef]

155. Chong, E.S.L. A potential role of probiotics in colorectal cancer prevention: A review of possible mechanisms of action. Best Pract. Res. Clin. Gastroenterol. 2014, 30, 351-374. [CrossRef] [PubMed]

156. Faghfoori, Z.; Gargari, B.P.; Gharamaleki, A.S.; Bagherpour, H.; Khosroushahi, A.Y. Cellular and molecular mechanisms of probiotics effects on colorectal cancer. J. Funct. Foods 2015, 18, 463-472. [CrossRef]

157. Pagnini, C.; Corleto, V.D.; Hoang, S.B.; Saeed, R.; Cominelli, F.; Delle Fave, G. Commensal bacteria and "oncologic surveillance": Suggestions from an experimental model. J. Clin. Gastroenterol. 2008, 42, S193-S196. [CrossRef]

158. Kumar, R.S.; Kanmani, P.; Yuvaraj, N.; Paari, K.; Pattukumar, V.; Thirunavukkarasu, C.; Arul, V. Lactobacillus plantarum AS1 isolated from south Indian fermented food Kallappam suppress 1,2-dimethyl hydrazine (DMH)-induced colorectal cancer in male Wistar rats. Appl. Biochem. Biotechnol. 2012, 166, 620-631. [CrossRef]

159. Lin, P.W.; Myers, L.E.; Ray, L.; Song, S.-C.; Nasr, T.R.; Berardinelli, A.J.; Kundu, K.; Murthy, N.; Hansen, J.M.; Neish, A.S. Lactobacillus rhamnosus blocks inflammatory signaling in vivo via reactive oxygen species generation. Free Radic. Biol. Med. 2009, 47, 1205-1211. [CrossRef]

160. Mohania, D.; Kansal, V.K.; Sagwal, R.; Shah, D. Anticarcinogenic effect of probiotic Dahi and piroxicam on DMH-induced colorectal carcinogenesis in Wistar rats. Am. J. Phys. 2013, 1, 8-24.

161. Shida, K.; Kiyoshima-Shibata, J.; Nagaoka, M.; Watanabe, K.; Nanno, M. Induction of interleukin-12 by Lactobacillus strains having a rigid cell wall resistant to intracellular digestion. J. Dairy Sci. 2006, 89, 3306-3317. [CrossRef]

162. Jahani-Sherafat, S.; Alebouyeh, M.; Moghim, S.; Amoli, H.A.; Ghasemian-Safaei, H. Role of gut microbiota in the pathogenesis of colorectal cancer; a review article. Gastroenterol. Hepatol. Bed Bench 2018, 11, 101. [PubMed]

163. Zhu, Q.; Gao, R.; Wu, W.; Qin, H. The role of gut microbiota in the pathogenesis of colorectal cancer. Tumor Biol. 2013, 34, 1285-1300. [CrossRef] [PubMed]

164. Den Besten, G.; Van Eunen, K.; Groen, A.K.; Venema, K.; Reijngoud, D.-J.; Bakker, B.M. The role of short-chain fatty acids in the interplay between diet, gut microbiota, and host energy metabolism. J. Lipid Res. 2013, 54, 2325-2340. [CrossRef]

165. Macfarlane, G.T.; Macfarlane, S. Bacteria, colonic fermentation, and gastrointestinal health. J. AOAC Int. 2012, 95, 50-60. [CrossRef]

166. Nogal, A.; Valdes, A.M.; Menni, C. The role of short-chain fatty acids in the interplay between gut microbiota and diet in cardio-metabolic health. Gut Microbes 2021, 13, 1897212. [CrossRef] 
167. Ooi, L.-G.; Liong, M.-T. Cholesterol-lowering effects of probiotics and prebiotics: A review of in vivo and in vitro findings. Int. J. Mol. Sci. 2010, 11, 2499-2522. [CrossRef]

168. De Preter, V.; Raemen, H.; Cloetens, L.; Houben, E.; Rutgeerts, P.; Verbeke, K. Effect of dietary intervention with different pre-and probiotics on intestinal bacterial enzyme activities. Eur. J. Clin. Nutr. 2008, 62, 225-231. [CrossRef]

169. Nakamura, J.; Kubota, Y.; Miyaoka, M.; Saitoh, T.; Mizuno, F.; Benno, Y. Comparison of four microbial enzymes in Clostridia and Bacteroides isolated from human feces. Microbiol. Immunol. 2002, 46, 487-490. [CrossRef]

170. Hijová, E.; Kuzma, J.; Strojný, L.; Bomba, A.; Bertková, I.; Chmelárová, A.; Hertelyová, Z.; Kuliková, L.; Štofilová, J.; Ambro, L'. Effect of Lactobacillus plantarum LS/07 on intestinal bacterial enzyme activities in the prevention of cancer, atherosclerosis, and dysbiosis. Acta Vet. Beogr. 2016, 66, 294-303. [CrossRef]

171. Mroczynska, M.; Libudzisz, Z. Beta-glucuronidase and beta-glucosidase activity of Lactobacillus and Enterococcus isolated from human feces. Pol. J. Microbiol. 2010, 59, 265-269. [CrossRef]

172. Sadeghi-Aliabadi, H.; Mohammadi, F.; Fazeli, H.; Mirlohi, M. Effects of Lactobacillus plantarum A7 with probiotic potential on colon cancer and normal cells proliferation in comparison with a commercial strain. Iran. J. Basic Med. Sci. 2014, 17, 815.

173. Kim, S.-J.; Cho, S.Y.; Kim, S.H.; Song, O.-J.; Shin, I.-S.; Cha, D.S.; Park, H.J. Effect of microencapsulation on viability and other characteristics in Lactobacillus acidophilus ATCC 43121. LWT-Food Sci. Technol. 2008, 41, 493-500. [CrossRef]

174. Rowland, I.; Rumney, C.; Coutts, J.; Lievense, L. Effect of Bifidobacterium longum and inulin on gut bacterial metabolism and carcinogen-induced aberrant crypt foci in rats. Carcinogenesis 1998, 19, 281-285. [CrossRef] [PubMed]

175. Hatakka, K.; Holma, R.; El-Nezami, H.; Suomalainen, T.; Kuisma, M.; Saxelin, M.; Poussa, T.; Mykkänen, H.; Korpela, R. The influence of Lactobacillus rhamnosus LC705 together with Propionibacterium freudenreichii ssp. shermanii JS on potentially carcinogenic bacterial activity in the human colon. Int. J. Food Microbiol. 2008, 128, 406-410. [CrossRef]

176. Bruce, W.R. Recent hypotheses for the origin of colon cancer. Cancer Res. 1987, 47, 4237-4242. [PubMed]

177. Lidbeck, A.; Allinger, U.G.; Orrhage, K.; Ottova, L.; Brismar, B.; Gustafsson, J.-A.; Rafter, J.; Nord, C. Impact of Lactobacillus acidophilus supplements on the fecal microflora and soluble fecal bile acids in colon cancer patients. Microb. Ecol. Health Dis. 1991, $4,81-88$.

178. De Vrese, M.; Winkler, P.; Rautenberg, P.; Harder, T.; Noah, C.; Laue, C.; Ott, S.; Hampe, J.; Schreiber, S.; Heller, K.; et al. Effect of Lactobacillus gasseri PA 16/8, Bifidobacterium longum SP 07/3, B. bifidum MF 20/5 on common cold episodes: A double-blind, randomized, controlled trial. Clin. Nutr. 2005, 24, 481-491. [CrossRef]

179. Kawahara, T.; Takahashi, T.; Oishi, K.; Tanaka, H.; Masuda, M.; Takahashi, S.; Takano, M.; Kawakami, T.; Fukushima, K.; Kanazawa, H. Consecutive oral administration of Bifidobacterium longum MM-2 improves the defense system against influenza virus infection by enhancing natural killer cell activity in a murine model. Microbiol. Immunol. 2015, 59, 1-12. [CrossRef]

180. Liu, Y.; Liu, Q.; Jiang, Y.; Yang, W.; Huang, H.; Shi, C.; Yang, G.; Wang, C. Surface-displayed porcine IFN- $\lambda 3$ in Lactobacillus plantarum inhibits porcine enteric coronavirus infection of porcine intestinal epithelial cells. J. Microbiol. Biotechnol. 2020, 30, 515-525. [CrossRef]

181. Namba, K.; Hatano, M.; Yaeshima, T.; Takase, M.; Suzuki, K. Effects of Bifidobacterium longum BB536 administration on influenza infection, influenza vaccine antibody titer, and cell-mediated immunity in the elderly. Biosci. Biotechnol. Biochem. 2010, 74, 939-945. [CrossRef]

182. Panigrahi, P.; Parida, S.; Nanda, N.C.; Satpathy, R.; Pradhan, L.; Chandel, D.S.; Baccaglini, L.; Mohapatra, A.; Mohapatra, S.S.; Misra, P.R. A randomized synbiotic trial to prevent sepsis among infants in rural India. Nature 2017, 548, 407-412. [CrossRef]

183. Turner, R.B.; Woodfolk, J.A.; Borish, L.; Steinke, J.W.; Patrie, J.T.; Muehling, L.M.; Lahtinen, S.; Lehtinen, M.J. Effect of probiotic on innate inflammatory response and viral shedding in experimental rhinovirus infection-A randomized controlled trial. Benef. Microbes 2017, 8, 207-215. [CrossRef]

184. Waki, N.; Matsumoto, M.; Fukui, Y.; Suganuma, H. Effects of probiotic Lactobacillus brevis KB 290 on the incidence of influenza infection among schoolchildren: An open-label pilot study. Lett. Appl. Microbiol. 2014, 59, 565-571. [CrossRef]

185. Zelaya, H.; Alvarez, S.; Kitazawa, H.; Villena, J. Respiratory antiviral immunity and immunobiotics: Beneficial effects on inflammation-coagulation interaction during influenza virus infection. Front. Immunol. 2016, 7, 633. [CrossRef]

186. Hao, Q.; Dong, B.R.; Wu, T. Probiotics for preventing acute upper respiratory tract infections. Cochrane Database Syst. Rev. 2015, 21, Cd006895. [CrossRef]

187. Sugimura, T.; Takahashi, H.; Jounai, K.; Ohshio, K.; Kanayama, M.; Tazumi, K.; Tanihata, Y.; Miura, Y.; Fujiwara, D.; Yamamoto, N. Effects of oral intake of plasmacytoid dendritic cells-stimulative lactic acid bacterial strain on the pathogenesis of influenza-like illness and immunological response to influenza virus. Br. J. Nutr. 2015, 114, 727-733. [CrossRef]

188. Wang, B.; Hylwka, T.; Smieja, M.; Surrette, M.; Bowdish, D.M.; Loeb, M. Probiotics to prevent respiratory infections in nursing homes: A pilot randomized controlled trial. J. Am. Geriatr. Soc. 2018, 66, 1346-1352. [CrossRef]

189. Izumo, T.; Maekawa, T.; Ida, M.; Noguchi, A.; Kitagawa, Y.; Shibata, H.; Yasui, H.; Kiso, Y. Effect of intranasal administration of Lactobacillus pentosus S-PT84 on influenza virus infection in mice. Int. Immunopharmacol. 2010, 10, 1101-1106. [CrossRef]

190. Makino, S.; Sato, A.; Goto, A.; Nakamura, M.; Ogawa, M.; Chiba, Y.; Hemmi, J.; Kano, H.; Takeda, K.; Okumura, K. Enhanced natural killer cell activation by exopolysaccharides derived from yogurt fermented with Lactobacillus delbrueckii ssp. bulgaricus OLL1073R-1. J. Dairy Sci. 2016, 99, 915-923. [CrossRef] 
191. Luoto, R.; Ruuskanen, O.; Waris, M.; Kalliomäki, M.; Salminen, S.; Isolauri, E. Prebiotic and probiotic supplementation prevents rhinovirus infections in preterm infants: A randomized, placebo-controlled trial. J. Allergy Clin. Immunol. 2014, 133, 405-413. [CrossRef]

192. Jespersen, L.; Tarnow, I.; Eskesen, D.; Morberg, C.M.; Michelsen, B.; Bügel, S.; Dragsted, L.O.; Rijkers, G.T.; Calder, P.C. Effect of Lactobacillus paracasei subsp. paracasei, L. casei 431 on the immune response to influenza vaccination and upper respiratory tract infections in healthy adult volunteers: A randomized, double-blind, placebo-controlled, parallel-group study. Am. J. Clin. Nutr. 2015, 101, 1188-1196. [CrossRef]

193. Rodríguez-Díaz, J.; Monedero, V. Probiotics against digestive tract viral infections. Bioact. Food Diet Int. Liver Gastrointest. Dis. 2013, 271-284.

194. Al Kassaa, I.; Hober, D.; Hamze, M.; Chihib, N.E.; Drider, D. Antiviral potential of lactic acid bacteria and their bacteriocins. Probiotics Antimicrob. Proteins 2014, 6, 177-185s. [CrossRef]

195. Wan, L.; Chen, Z.; Shah, N.; El-Nezami, H. Modulation of intestinal epithelial defense responses by probiotic bacteria. Crit. Rev. Food Sci. Nutr. 2016, 56, 2628-2641. [CrossRef]

196. Iwabuchi, N.; Xiao, J.-Z.; Yaeshima, T.; Iwatsuki, K. Oral administration of Bifidobacterium longum ameliorates influenza virus infection in mice. Biol. Pharm. Bull. 2011, 34, 1352-1355. [CrossRef]

197. Chen, Y.-J.; Wang, S.-F.; Weng, I.-C.; Hong, M.-H.; Lo, T.-H.; Jan, J.-T.; Hsu, L.-C.; Chen, H.-Y.; Liu, F.-T. Galectin-3 enhances avian H5N1 influenza a virus-induced pulmonary inflammation by promoting NLRP3 inflammasome activation. Am. J. Pathol. 2018, 188, 1031-1042. [CrossRef]

198. Woodward, A.; Mauris, J.; Argüeso, P. Binding of transmembrane mucins to galectin-3 limits herpesvirus 1 infection of human corneal keratinocytes. J. Virol. 2013, 87, 5841-5847. [CrossRef]

199. Odun-Ayo, F.; Reddy, L. Potential roles of modified pectin targeting galectin-3 against Severe Acute Respiratory Syndrome Coronavirus-2. Multidiscip. Sci. J. 2021, 4, 824-837. [CrossRef]

200. Chong, H.-X.; Yusoff, N.A.A.; Hor, Y.-Y.; Lew, L.-C.; Jaafar, M.H.; Choi, S.-B.; Yusoff, M.S.; Wahid, N.; Abdullah, M.F.I.; Zakaria, N. Lactobacillus plantarum DR7 improved upper respiratory tract infections via enhancing immune and inflammatory parameters: A randomized, double-blind, placebo-controlled study. J. Dairy Sci. 2019, 102, 4783-4797. [CrossRef]

201. Garcia-Crespo, K.E.; Chan, C.C.; Gabryszewski, S.J.; Percopo, C.M.; Rigaux, P.; Dyer, K.D.; Domachowske, J.B.; Rosenberg, H.F. Lactobacillus priming of the respiratory tract: Heterologous immunity and protection against lethal pneumovirus infection. Antivir. Res. 2013, 97, 270-279. [CrossRef]

202. Paolillo, R.; Carratelli, C.R.; Sorrentino, S.; Mazzola, N.; Rizzo, A. Immunomodulatory effects of Lactobacillus plantarum on human colon cancer cells. Int. Immunopharmacol. 2009, 9, 1265-1271. [CrossRef]

203. Gao, Q.Y.; Chen, Y.X.; Fang, J.Y. 2019 Novel coronavirus infection and gastrointestinal tract. J. Dig. Dis. 2020, 21, 125. [CrossRef]

204. Baindara, P.; Chakraborty, R.; Holliday, Z.M.; Mandal, S.M.; Schrum, A.G. Oral probiotics in coronavirus disease 2019: Connecting the gut-lung axis to viral pathogenesis, inflammation, secondary infection and clinical trials. New Microbes New Infect. 2021, 40, 4783-4797. [CrossRef] 